\title{
The Process of Negotiating Settlements at FERC
}

\author{
Stephen Littlechild
}

January 2011

CWPE 1116 \& EPRG 1105 


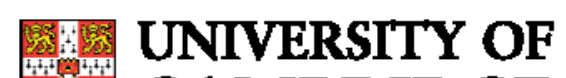 \\ CAMBRIDGE \\ Electricity Policy \\ Research Group
}

\section{The process of negotiating settlements at FERC}

\author{
EPRG Working Paper 1105 \\ Cambridge Working Paper in Economics 1116
}

\section{Stephen Littlechild}

\begin{abstract}
Interstate gas pipelines and their customers presently settle about $90 \%$ of the rate cases set for hearing before the Federal Energy Regulatory Commission (FERC). This paper sets out the process by which this is achieved, illustrating with the 12 rate cases from 2008 and 2009. In contrast to many other jurisdictions, FERC Trial Staff play an active role in facilitating negotiation and settlement. They propose a first settlement offer 3 months after a pipeline files for a tariff rate increase. Thereafter, the regulatory aim is to bring the parties into agreement, not to impose an outcome upon them. This is a different role for the regulatory body than was previously apparent. The process has worked increasingly successfully and essentially unchanged for over 35 years. The conventional regulatory litigation process is now only an occasional means of dispute resolution. The paper also discusses and illustrates why parties prefer settlement to litigation, what difference it makes, which cases tend to settle, what might account for the increasing frequency of settlements over time, the recent phenomenon of pre-filing settlements and the settlement of section 5 (rate reduction) cases brought by FERC.
\end{abstract}

Keywords

JEL Classification

Contact

Publication

Financial Support
Regulation, negotiated settlement

$$
\text { L51, L95 }
$$

sclittlechild@tanworth.mercianet.co.uk January 2011; Revised Version: May 2011 ESRC Follow-on Fund COUNCIL 


\title{
The process of negotiating settlements at FERC
}

\author{
Stephen Littlechild ${ }^{1}$ \\ Emeritus Professor, University of Birmingham, and \\ Fellow, Judge Business School, University of Cambridge
}

Original Publication: January 2011

Revised Version: May 2011

\section{Introduction}

The Federal Energy Regulatory Commission (FERC) has jurisdiction over interstate oil and gas pipelines and electricity transmission systems. A high and apparently increasing proportion of rate cases before it are settled by negotiation between the parties, rather than by litigation.

- Between 1961 and 1970 about 56\% of the natural gas pipeline rate cases at the predecessor to FERC, the Federal Power Commission (FPC), were settled in whole or in part. (Spritzer 1971)

- As of 1980, settlements were reached in approximately two-thirds (66\%) of all electric utility rate cases. (FERC staff 1980 per Wang 2004)

- As of 1986, over 70\% of pipeline rate cases were settled. (Walker 1986)

- Over many recent years, "approximately $80 \%$ of the contested proceedings set for hearing at the Commission are settled". (FERC 2010 p. 18)

- During 2007-09, 90\% of cases set for hearing achieved partial or complete consensual agreement. (FERC 2010 pp. 88-92)

In the one detailed study, Wang found that 38 out of 40 section 4 rate applications brought by large natural gas pipelines during 1994-2000 were settled in whole or in part, and only 2 litigated. That is, there was settlement in whole or in part in $95 \%$ of these cases. In addition, the one section 5 case brought by FERC was settled.

Settlement makes a dramatic difference to processing times. In 1980 FERC's average processing time for general electric rate cases was 14 months for uncontested settlements, compared to 37 months for contested settlements and 50 months for fully litigated rate cases. (Wang reporting FERC Staff) These orders of magnitude still obtain. Wang found the average time to settle most gas pipeline rate cases during the

\footnotetext{
${ }^{1}$ I am grateful to Ralph Leslie and Kenneth Sosnick at FERC for patient explanation of these issues and for helpful data. Discussions with Richard O'Neill, Anna Cochrane, Richard Howe and Judge Michael Cianci (FERC), Irwin Steltzer, Linda Stuntz (Stuntz, Davis \& Staffier, P.C.), Bill Hogan, Patricia Jagtiani and colleagues (Natural Gas Supply Association), Kelly Daly (Stinson, Morrison Hecker LLP), Frank Lindh (California PUC), Scott Hempling (NRRI), Kevin Huntsman (Mastio \& Co) and many others provided further insights. Comments and suggestions of three referees have been helpful. I thank Ofwat for partial support to write up the early material, and the EPRG Group at Cambridge University for contribution towards travel expenses.
} 
late 1990s was about one year, plus the time for FERC to approve them (which ranged from about 1 to 13 months with a median of about $3 \frac{1 / 2}{2}$ months). In contrast, one of the two litigated cases took about $3 \frac{1}{2} 2$ years to process, the other about $5 \frac{1}{2} 2$ years.

Walker set out some procedural aspects of settlement at FERC. Rosenzweig and Shuttleworth (2008) briefly outline FERC's present procedures but do not discuss how settlements are facilitated. There has been discussion of the legal context surrounding settlements, including their status and appropriateness, and in particular with respect to non-unanimous or contested settlements. (Drom 1991, Krieger 1995, and literature survey by Doucet and Littlechild 2006) Buchmann and Tongeren (1996) have drawn attention to the qualitative difference in the nature of negotiated outcomes compared to litigated outcomes. Wang has documented this with FERC cases. These authors attribute the different outcomes to negotiations taking the case as a whole whereas litigation takes each issue on a line by line basis.

In the past, some jurisdictions may have discouraged settlements. Increasingly, there seems to be sympathy for them. However, there has been no systematic survey of the general picture in North America. Littlechild (2009a,b) has examined which kinds of cases tend to be settled or not settled in Florida (generally, rate reductions are settled but not rate increases), and has contrasted the outcomes with those of the litigated process. Doucet and Littlechild (2009) have documented the development of settlements at the National Energy Board (NEB) in Canada.

Why are such a high proportion of cases settled at FERC? In Florida and Canada the parties themselves negotiate the settlements with little or no role for the regulator. It might be assumed that the same 'hands-off' approach is adopted at FERC.

In fact, however, the opposite is true. FERC Trial Staff are actively involved at each stage of the settlement process. They present what is known as a 'first settlement offer' in response to a pipeline proposal to change rates. This is Trial Staff's own view of what would be a reasonable outcome. Thereafter, Trial Staff actively seek to facilitate agreement between the parties, including by multilateral and bilateral discussions and by presenting and analysing further counter offers as necessary.

This paper provides a detailed account of how the settlement process at FERC actually works in practice with respect to gas pipeline rate cases. (The process for dealing with electricity transmission systems is similar but differs in one main respect, as explained below.) To give some indication of the time involved at each stage of the process, the paper presents data from the 12 pipeline rate cases brought during fiscal years 2008 and 2009, of which 9 were settled in full and 2 in part, and 1 was litigated.

The justification for describing FERC's active regulatory process in some detail is twofold. First, negotiated settlement has now become the standard process for setting interstate gas and electricity rates: the previously conventional litigated approach is essentially reserved for occasional dispute resolution (though of course its existence influences the content of the settlements). Among regulatory bodies, settlement is most pervasive at FERC - yet no account of its pro-active settlement process presently exists, and indeed there is no hint of it in the economic regulation literature. 
Second, it is hoped that the account will also be of relevance in other contexts where changes to regulatory arrangements are under discussion and where negotiated settlement is essentially unknown. In the UK, for example, interest in the concept of settlements is tempered by a concern that some parties (particularly smaller customers) would thereby lose access to regulatory information, opinion, guidance and support. A better understanding of actual regulatory involvement at FERC should provide some reassurance and facilitate the improvement of regulatory arrangements there and elsewhere. This is not to argue, of course, that arrangements at FERC are directly applicable in the UK or in State jurisdictions or elsewhere. ${ }^{2}$

Apart from the process, the nature and outcome of settlements are of interest. Why do parties settle? What if any difference do settlements make? What kinds of cases tend to settle? What if anything has been the trend over time and why? The paper discusses what light can be shed on these and other questions by the FERC data examined here. It also looks at two recent trends: the pre-filing of settlements before filing rate changes with FERC and the settling of section 5 (rate reduction) cases brought by FERC.

\section{Gas industry background}

FERC regulates over 170 interstate natural gas pipeline systems of which 128 are large enough to file regular information via Forms 2 and 2A. ${ }^{3}$ In 2008 the Top 30 pipelines (in terms of system capacity) ranged from nearly 16,000 miles in length to under 1000 miles and accounted for nearly three-quarters of total interstate system capacity. Two or three new pipelines are constructed each year. Some pipelines are small, less than 100 miles long, often connecting to other pipelines. Others are longer: the Rockies Express commissioned in November 2009 was an expansion of some 1500 miles.

The customers of these pipelines typically comprise i) gas producers ii) gas marketers iii) large end-users including power plants, and iv) local gas distribution (delivery) companies (LDCs) who in turn sell to smaller end-users. These parties may be at either end of the pipeline or at any point(s) along it.

Customers wish to avoid excessive transportation rates. They may be subject to competition, including from other fuels. The pipeline is also subject to some degree of competition from other pipelines. A distribution company, particularly in a larger city, might be hooked up to two or more pipelines, thereby giving it a degree of choice as to which to use. Some larger distribution companies are hooked up to as many as seven

\footnotetext{
${ }^{2}$ For example, most UK utility customers are smaller, more numerous and less-informed than those appearing before FERC, and UK regulatory bodies do not have separate Trial Staff, Advisory Staff and Administrative Law Judges. On the other hand, it goes too far to claim that the use of negotiated settlements "would require far-reaching reforms to British regulatory procedures (and laws)" and "cannot function without the transfer or introduction of several other regulatory institutions and legal principles" (Rosenzweig and Shuttleworth 2008), and that "regulatory settlements only work if the regulators have previously written down in immense detail exactly how they would carry out a formal regulatory review, so that everyone can predict the likely outcome" (Shuttleworth 2008).

${ }^{3}$ FERC's three digit pipeline code lists 232 gas pipelines. Its list of regulated entities comprises 157 gas pipelines plus 17 Gulf offshore pipelines. Some 84 Major pipelines (volume exceeding 50m dekatherms) presently provide quarterly and annual financial and operational information via Form 2, while 44 Non-Major pipelines (volume between $200 \mathrm{k}$ and $50 \mathrm{~m}$ dekatherms) complete a simpler Form 2A. The FPC was renamed FERC in 1977.
} 
pipelines. Each pipeline offers access to a number of different producers. Some pipelines have as many as 10,000 supply points where producers can input gas.

Gas distribution companies are not subject to competition, but are subject to regulation by State public utility commissions. The distribution companies' incentive to argue for lower rates may be limited insofar as they are typically allowed to pass the costs of transportation through to final customers. Moreover, if they argue for a lower allowed return on capital they may find that their State regulatory commissions argue for a comparably lower cost of capital for themselves. Similarly, some of the pipeline's customers may feel that they have to 'pull their punches' in order to maintain a working relationship with the pipeline, including in acting together in promoting the industry.

However, the State public utility commissions themselves typically act as intervenors (interested parties) in FERC cases, and in practice play a major role in the settlement process. They generally argue on behalf of end-customers, especially smaller ones, although commissions in predominantly 'producer' states may be less active.

The number of participants in any rate case will vary, depending perhaps on the size of the pipeline or the size or nature of rate change proposed. Reportedly, most of the customers are represented in each case. Other intervenors may include rival pipelines and potential (as opposed to actual) customers.

\section{Section 4 and 5 rate cases}

A pipeline has a 'right to rely on the rate on file' - that is, it is entitled to charge the rates and provisions in the tariff determined by the most recent FERC decision. (Tariff provisions include quality of service obligations.) Whoever wishes to change those tariffs bears the burden of proof that the existing tariffs are unjust and unreasonable, and that proposed new tariffs would be just and reasonable.

Under section 4 of the Natural Gas Act 1938, a gas pipeline has the right to file for a change in tariffs at any time. FERC has 30 days in which to respond. It may then suspend a new tariff for a maximum of five months, while it investigates and holds hearings. Thereafter the pipeline has the right to implement the new tariff until FERC makes a determination. However, FERC may order a 'suspension subject to refund', whereby such proportion of the changed revenues that is subsequently disallowed is refunded to customers, backdated to when the new tariffs were implemented.

Under section 5 of the Act, FERC is authorized to investigate the tariffs charged by a pipeline, either on its own initiative or after complaint by a third party. FERC and any third party bear the burden of proof if they wish to change the tariffs. In the event of a finding that tariffs are no longer just and reasonable, FERC may not order a refund. ${ }^{4}$

\footnotetext{
${ }^{4}$ This is said to give a pipeline the incentive to spin out a section 5 case (although recent section 5 cases have been settled relatively quickly - see below). There is presently active discussion whether to allow refunds dating back to the time of filing a section 5 case, as is already the case in the electric sector, which could encourage the bringing of section 5 cases by other parties.
} 


\section{Order 636 and the number of rate cases}

Until 1992, gas pipelines not only transported gas but typically also bought and sold gas. Because gas purchase costs tended to fluctuate, pipelines were allowed a Purchased Gas Adjustment (PGA) clause that tracked gas purchase costs each $6-12$ months with a periodic true-up. In return for that automatic pass-through right, the pipelines as gas suppliers were required to make a section 4 filing of their pipeline transportation and storage rates every 3 years.

FERC Order 636, issued on 8 April 1992, restructured the gas pipeline sector by requiring the unbundling (separation) of gas production, transportation and sales activities with a view to increasing competition among gas sellers and reducing the market power of pipeline companies. Once gas pipelines were no longer involved in gas purchase and sales they no longer had the PGA clause, hence there was no obligation to make a section 4 rate filing every 3 years.

This had a dramatic impact on the number of rate cases. Before 1992, with about 128 pipelines filing every three years, there would presumably have been over 40 pipeline rate cases per year. In contrast, on average there have been less than 7 pipeline rate cases per year since $1998 .^{5}$

This means that, in practice, many pipelines are no longer involved in the traditional regulatory process. ${ }^{6}$ During the dozen years 1998-2009, 1 pipeline had four section 4 rate filings, 5 had three filings, 14 had two filings and 6 had one filing - a total of about 26 pipelines. It seems that over 100 pipelines were not involved in section 4 rate cases during that period. Some have not filed since $1992{ }^{7}$

It is perhaps surprising that most pipelines have been prepared to accept the rates on file over a quite long period of time. Since rates are effectively fixed in nominal terms, inflation might be expected to reduce pipeline returns over time. Non-filing may imply that many pipelines have offset inflation by increased efficiency and lower costs as a result of increased competition and/or from the incentive effect of not having to file lower rates to reflect lower costs. Also, pipelines may prefer to accept lower fixed rates

5 FERC lists 83 rate filings over the 12 calendar years 1998-2009. (www.ferc.gov/industries/gas/gen-info/rate-filings) A few of these were compliance filings rather than proposed new rates. Wang found similar figures for the largest pipelines over the period 1994-2000.

6 "During the slightly over six-year period, 24 pipelines filed one general section 4 rate case, eight filed two, and 11 did not file any general rate case." (Wang p. 144) There could have been other minor filings. "A pipeline usually files a much larger number of limited section 4 rate cases, for example, to change the characteristics of its services or recover specific cost items outside the firm's control." (Wang p. 144)

7 A National Gas Supply Association (NGSA) analysis of the top 17 earning pipelines in the five years 2003-2007 found that one had an ongoing rate case, 8 had last filed in the previous 5 years and the other 8 had not filed for periods ranging from 9 to 19 years before the study date of 7 December 2009. 
rather than subject themselves to the intense scrutiny and possible adverse consequences of a section 4 rate case. ${ }^{8}$

FERC has published no general analysis of pipeline returns. Users have made some calculations that show a range of returns. ${ }^{9}$ Perhaps in response to such analyses and attendant pressures, FERC has recently brought five section 5 cases.

\section{FERC's internal organization}

FERC is an independent agency whose responsibilities include the regulation of interstate transmission of electricity, natural gas and oil. It has up to five Commissioners serving 5 year terms, plus about 1350 staff organized into eleven Offices. Three Offices are of particular relevance here.

The Office of Energy Market Regulation (OEMR), which has about 240 staff known as 'Advisory Staff', "advises the Commission and processes caseload related to economic regulation”. The OEMR is responsible (inter alia) for receiving a section 4 application and issuing a 'suspension order' (see below) which hands over important parts of the process to the other Offices. In a gas pipeline rate case this includes ordering a hearing and arranging for the appointment of a judge to preside over the hearing. The OEMR will also advise on and initiate a section 5 case following a decision of the Commission.

The Office of Administrative Law Judges is charged to "Resolve contested cases as directed by the Commission effectively, efficiently and expeditiously, either through impartial hearing and decision or through negotiated settlement, ensuring that the rights of all parties are preserved." This Office comprises about 15 independent Administrative Law Judges (ALJs) plus about 20 support staff. ${ }^{10}$

The Office of Administrative Litigation (OAL) is charged to "represent the public interest and seek to litigate or settle cases in a timely, efficient and equitable manner while ensuring the outcomes are consistent with Commission policy". " The OAL has

\footnotetext{
${ }^{8}$ For earlier discussion of Order 636 and its effects, see Doane and Spulber (1994), De Vany and Walls (1994), Gorak and Ray (1995), Herbert and Kreil (1996), Dahl and Matson (1998) and Chermak (1998).

9 The NGSA's analysis of 32 major pipelines showed that, over the five years 2004-2008, the weighted average return on equity was 14.4\%. 19 pipelines had an average return exceeding $12 \%$, of which 5 had an average return exceeding 20\%. 12 pipelines had average returns ranging from $11.2 \%$ down to $5.9 \%$ and one had an average of $-6.0 \%$.

10 "Functions of the presiding judge include: Managing and presiding over hearings and investigations on-the-record; Issuing orders; Issuing initial decisions; Issuing reports to the Commission; Overseeing Discovery; Acting on motions filed in a case; Making findings of fact; Certifying questions to the Commission; Reviewing and certifying settlements to the Commission; and Summarily disposing of cases." (www.ferc.gov)

11 "Functions of the FERC Trial Staff include: conducting needed discovery (obtaining information from other parties); performing detailed analysis of data to develop testimony and exhibits; supporting such testimony through cross examination in hearings; preparing and presenting oral arguments, and conducting direct and cross examination in proceedings before ALJs; preparing and filing legal briefs;

ensuring that the evidentiary record developed in each case is adequate for decision making by the ALJ and the Commission, while meeting all required deadlines; developing and serving on all parties objective settlement positions (top sheets); conducting or participating in settlement
} 
about 110 staff known as 'Trial Staff' or 'Litigation Staff'. A major part of this paper explains how Trial Staff discharge these duties in gas pipeline rate cases.

The preliminary outcome of each case is either a negotiated settlement or a hearing (or sometimes a combination). The ALJ certifies the settlement to the Commission (see below) and/or issues an initial decision following a hearing. OEMR Advisory Staff advise Commissioners, who decide whether to approve the settlement or the initial ALJ decision. On any particular case, OEMR Advisory Staff and OAL Trial Staff are prohibited from communicating with each other. ${ }^{12}$

Electricity and gas cases differ in one respect. In the case of an electricity transmission system, and in a few gas pipeline cases, the OEMR's suspension order appoints an Administrative Law Judge (ALJ) to chair the settlement process instead of leaving this to Trial Staff. ${ }^{13}$ In other respects Trial Staff perform the role as described in this paper. Only after the settlement process is concluded (successfully or unsuccessfully) does the Commission set in motion a hearing process with a (different) hearing judge. ${ }^{14}$

\section{Section 4 rate cases 2008 - 2009}

This paper illustrates FERC processes with the 12 section 4 rate cases filed in the two fiscal years 2008 and 2009 (i.e. from 1 October 2007 to 30 September 2009). The timelines are set out in Table 1. Nine of these cases were settled in full and two in part, and one was litigated. In three cases, aspects of FERC's decisions are still outstanding. Table 2 (see later) sets out some of the main features of these cases. Briefly, 9 of the pipelines sought rate increases (in 4 cases partially reflecting earlier investment), 2 sought rate decreases (partially reflecting increased volumes). In about half the cases the proposals also involved surcharges or tracker mechanisms, and in about half the cases there were also new or redefined services or changes in terms and conditions.

processes with energy industry officials, state commissions, customers and other intervening parties; and assisting the settlement judge and parties to ensure agreements are consistent with Commission policy." (ibid.)

12 More generally, there is a degree of separation between these three Offices that is mirrored (sometimes to a lesser extent) in the larger US State utility regulation commissions but is not found in (e.g.) UK utility regulation commissions.

13 The parties are offered a list of, say, eight available ALJs, so they can choose one whose experience or style they deem appropriate to the case. An ALJ acting in this capacity is referred to as a 'settlement judge', whereas acting in the other capacity is variously described as a 'hearing judge', a 'presiding judge' or a 'trial judge'. A settlement judge may give views on the credibility of the arguments of each party, either in front of all parties, or to each party in private. With different styles, settlement judges make a strong effort to bring about unanimous settlements. They will not normally recommend acceptance of a settlement if Trial Staff object.

${ }^{14}$ It is not clear why FERC processes for gas and electricity differ in this way. ALJs are generally experienced in both sectors, but in the gas sector there are typically a greater number of parties with more different interests, dealing with more complex issues than in electricity. It has been suggested to me that specialist gas Trial Staff are more familiar with gas issues than an ALJ would be. Reportedly, the parties and FERC are content with the approach in each sector, and do not seek to change it. 
Table 1: Timeline of Section 4 Natural Gas Pipeline Rate Cases at FERC (2008 and 2009)

\begin{tabular}{|c|c|c|c|c|c|c|c|c|}
\hline Pipeline Company & Docket No. & $\begin{array}{l}\text { Rate Case } \\
\text { Filing } \\
\end{array}$ & Suspension Order & $\begin{array}{l}\text { Staff } \\
\text { Top Sheet } \\
\text { (assumed } \\
90 \text { days) } \\
\end{array}$ & $\begin{array}{l}\text { Settlement } \\
\text { Filed }\end{array}$ & $\begin{array}{l}\text { ALJ } \\
\text { Settlement Certified } \\
\text { and/or initial decision }\end{array}$ & $\begin{array}{l}\text { Commission } \\
\text { Approval of } \\
\text { Settlement } \\
\text { and/or final } \\
\text { decision } \\
\end{array}$ & Present status \\
\hline Saltville Gas Storage & $\begin{array}{l}\text { RP08-257- } \\
000\end{array}$ & $03 / 04 / 2008$ & 04/02/2008 (29 days) & $07 / 01 / 2008$ & $\begin{array}{l}\begin{array}{l}10 / 7 / 2008 ~(98 \\
\text { days) }\end{array} \\
\end{array}$ & 10/29/2008 (22 days) & $\begin{array}{l}12 / 02 / 2008 \text { (34 } \\
\text { days) }\end{array}$ & Settlement, Completed \\
\hline Portland Natural Gas & $\begin{array}{l}\text { RP08-306- } \\
000\end{array}$ & $04 / 01 / 2008$ & 05/01/2008 (30 days) & 07/23/2008 & $\begin{array}{l}\text { 5/11/2009 (292 } \\
\text { days) }\end{array}$ & $\begin{array}{l}06 / 18 / 2009 \text { part (38 } \\
\text { days) } \\
12 / 24 / 2009 \text { rest (514 } \\
\text { days) } \\
\end{array}$ & $\begin{array}{l}09 / 23 / 2009 \text { (97 } \\
\text { days) } \\
2 / 17 / 2011 \text { (420 } \\
\text { days) } \\
\end{array}$ & $\begin{array}{l}\text { Partial settlement, } \\
\text { Completed }\end{array}$ \\
\hline Southern Star Central & $\begin{array}{l}\text { RP08-350- } \\
000\end{array}$ & $04 / 30 / 2008$ & 05/29/2008 (29 days) & $08 / 27 / 2008$ & $\begin{array}{l}\begin{array}{l}12 / 11 / 2008 \text { (99 } \\
\text { days) }\end{array} \\
\end{array}$ & 01/13/2009 (33 days) & $\begin{array}{l}\text { 06/01/2009 (139 } \\
\text { days) }\end{array}$ & Settlement, Completed \\
\hline El Paso Natural Gas & $\begin{array}{l}\text { RP08-426- } \\
000\end{array}$ & $06 / 30 / 2008$ & 08/05/2008 (33 days) & $11 / 03 / 2008$ & $\begin{array}{l}\text { 3/11/2010 (493 } \\
\text { days) }\end{array}$ & $\begin{array}{l}04 / 13 / 2010 \text { part (33 } \\
\text { days) } \\
01 / 14 / 2011 \text { rest (802 } \\
\text { days) } \\
\end{array}$ & $\begin{array}{l}04 / 28 / 2010(15 \\
\text { days }) \\
(>123 \text { days*) }\end{array}$ & $\begin{array}{l}\text { Partial settlement } \\
\text { approved, } \\
\text { FERC dec'n on rest } \\
\text { awaited } \\
\end{array}$ \\
\hline Stingray Pipeline Co & $\begin{array}{l}\text { RP08-436- } \\
000\end{array}$ & $06 / 30 / 2008$ & 07/30/2008 (30 days) & $10 / 28 / 2008$ & $\begin{array}{l}\text { 3/25/2009 (148 } \\
\text { days) }\end{array}$ & 04/20/2009 (26 days) & $\begin{array}{l}\text { 06/29/2009 (70 } \\
\text { days) }\end{array}$ & Settlement, Completed \\
\hline Paiute Pipeline Co & $\begin{array}{l}\text { RP09-406- } \\
000\end{array}$ & $02 / 27 / 2009$ & 03/31/2009 (32 days) & $06 / 29 / 2009$ & $\begin{array}{l}\text { 11/3/2009 (127 } \\
\text { days) }\end{array}$ & 11/19/2009 (16 days) & $\begin{array}{l}\text { 03/26/2010 (127 } \\
\text { days) }\end{array}$ & Settlement, Completed \\
\hline Southern Natural Gas Co. & $\begin{array}{l}\text { RP09-427- } \\
000\end{array}$ & $03 / 02 / 2009$ & 04/01/2009 (29 days) & $06 / 30 / 2009$ & $\begin{array}{l}\text { 10/5/2009 (97 } \\
\text { days) }\end{array}$ & 10/20/2009 (15 days) & $\begin{array}{l}\text { 01/05/2010 (77 } \\
\text { days) }\end{array}$ & Settlement, Completed \\
\hline $\begin{array}{l}\text { High Island Offshore } \\
\text { System }\end{array}$ & $\begin{array}{l}\text { RP09-487- } \\
000\end{array}$ & $03 / 31 / 2009$ & 04/30/2009 (30 days) & 07/29/2009 & $\begin{array}{l}\text { 3/15/2010 (229 } \\
\text { days) }\end{array}$ & 04/23/2010 (39 days) & $\begin{array}{l}\text { 04/29/2011 (371 } \\
\text { days) } \\
(>389 \text { days*) }\end{array}$ & $\begin{array}{l}\text { Settlement approved, } \\
\text { FERC dec'n on res'vd } \\
\text { issue awaited }\end{array}$ \\
\hline MoGas Pipeline & $\begin{array}{l}\text { RP09-791- } \\
000\end{array}$ & $06 / 30 / 2009$ & 07/29/2009 (29 days) & $10 / 27 / 2009$ & $\begin{array}{l}\text { 3/16/2010 (140 } \\
\text { days) }\end{array}$ & 03/24/2010 (8 days) & $\begin{array}{l}\text { 07/30/2010 (128 } \\
\text { days) }\end{array}$ & Settlement, Completed \\
\hline Maritimes \& NE Pipeline & $\begin{array}{l}\text { RP09-809- } \\
000\end{array}$ & $07 / 01 / 2009$ & 07/30/2009 (29 days) & $10 / 28 / 2009$ & $\begin{array}{l}\text { 3/4/2010 (137 } \\
\text { days) }\end{array}$ & 03/18/2010 (4 days) & $\begin{array}{l}04 / 30 / 2010 \text { (43 } \\
\text { days) }\end{array}$ & Settlement, Completed \\
\hline Sea Robin Pipeline Co & $\begin{array}{l}\text { RP09-995- } \\
000\end{array}$ & $08 / 31 / 2009$ & 09/30/2009 (30 days) & $12 / 29 / 2009$ & No Settlement & 12/13/2010 (349 days) & $(>155$ days $*)$ & FERC decision awaited \\
\hline
\end{tabular}




\section{Settlement Regulations}

The Administrative Procedure Act requires FERC to "give all interested parties opportunity for ... offers of settlement". Indeed, the statute gives priority to settlement insofar as FERC is required to hold a hearing and give a decision "to the extent that the parties are unable so to determine a controversy by consent”. (Walker, p. 343)

The conduct of the settlement practice is governed by regulations promulgated by FERC itself. ${ }^{15}$ These encourage participation in formal and informal settlement conferences. Failure of a party to attend a formal settlement conference will constitute a waiver to all objections to any order or ruling or agreement arising out of it. All participants attending a formal conference must be prepared to discuss the matters to be addressed. Informal settlement conferences are not governed by notice and participation requirements. In practice informal rather than formal conferences seem to be the norm.

Generally speaking, the Commission tends to set rate issues for hearing and settlement procedures, and to set proposed changes in terms and conditions for a Technical Conference after which the Commission may make an order. The aim of the conference is to better inform Advisory Staff about operational issues prior to advising on Commission decisions (although some customers may use these operational issues as leverage in settlement negotiations, and it is also possible for settlements to include operational issues if the Commission has not yet issued an order). There may also be a Discovery Conference, either with the parties alone or including the ALJ, to set the parameters of discovery such as time allowed to respond to data requests. (In one case this determined whether the Public Service Commission was allowed to enter and inspect a pipeline compressor station.)

The extent of discovery of information is influenced by the possibility of settlement. For example, under litigation procedures a pipeline might only be required to provide information pertaining to the specified test year. But if settlement is in prospect the pipeline might be asked for - and might be willing to provide - information over the last ten years to establish the existence or otherwise of a cyclical effect. Similarly as to timing: a pipeline might not be required to provide information until a Technical Conference is complete and a hearing judge is appointed, but it might be willing to do so earlier in order to facilitate the prospect of settlement.

Any participant may submit an offer of settlement at any time, together with relevant explanatory material. This goes to all the participants, who are invited to comment within 20 days, with reply comments within a further 10 days.

If a settlement is reached, the parties are required to provide an Explanatory Statement. ${ }^{16}$ If a settlement offer is uncontested (unanimous), and the explanatory statement does not raise issues, the ALJ 'certifies' it to the Commission. The

\footnotetext{
${ }^{15}$ Code of Federal Regulations, Rules of Practice and Procedure, Sections 385.601-606.

16 This addresses five questions on which the ALJ must advise the Commission, indicating whether the settlement raises any new policy issues or reverses the Commission's previous stance. In practice the Explanatory Statement usually answers each of these questions in a brief sentence or two, as does the ALJ's subsequent certification to the Commission.
} 
Commission may approve an uncontested settlement upon a finding that it appears to be fair and reasonable and in the public interest.

If a settlement is not unanimous, and is contested by any party in whole or in part, the Commission can "sever" the contested issues from the uncontested ones and deal with the uncontested ones as just mentioned. It can determine the merits of the contested issues "if the record contains substantial evidence on which to base a reasoned decision or the Commission determines there is no genuine issue of material fact". The ALJ may certify a contested settlement if these conditions are met. Otherwise, the Commission has to take steps to receive additional evidence, typically by a litigated hearing.

All communications within settlement negotiations are privileged and confidential. In the event that agreement is not reached and the case subsequently goes to a hearing, the discussions between the parties with respect to earlier offers of settlement are not subject to discovery or admissible in evidence.

\section{Procedure for section 4 rate filings}

A pipeline will typically initiate a section 4 case by filing a submission for a rate increase. (Occasionally it might request a change in rate structure, or a rate reduction, or even no change in rates if it has been required to file simply by virtue of a previous settlement obligation.) The submission includes the revised 'tariff sheets' and all the supporting documents, including the company's relevant data on costs and cost allocation, volumes, depreciation rates and negative salvage (the cost of removal of retired plant). The submission also includes the direct testimony of all the company's staff and expert witnesses (e.g. on cost of capital). FERC publishes the filing for comment and then schedules a hearing (see below), though in practice a case is typically channelled towards a settlement.

Filings are substantial submissions: a smaller pipeline might file 300-400 pages, a larger pipeline over 1000 pages. This submission constitutes the pipeline's case in the event that the request is litigated. In principle, the pipeline should be ready to defend the case the next day. Preparation is therefore significant, and takes 3 to 6 months. This includes a pre-filing meeting with Advisory Staff to check that no aspects of the filing will prevent it being duly processed, and pre-filing meetings with state regulators (almost always) and key customers (usually).

\section{Suspension order}

On receipt of a notice of filing, interested parties request permission to become intervenors in the process. They may at the same time file initial objections to the proposed rate change. These responses are public, as are all the communications and decisions in the case apart from settlement discussions. The number of intervenors varies from case to case: in the 9 sample cases that were settled the number ranged from 6 to over 50, with a mean of 16 and a median of 10 . The number of interested parties is actually higher insofar as some intervenors are groups of parties. ${ }^{17}$

17 For example, in the Southern Natural case 18 intervenors were listed, but this included the Alabama Municipal Distributors Group (23 members), the East Tennessee Group of local utilities 
FERC has 30 days to act on the submission. Typically, at the end of this period Advisory Staff issue a 'suspension order', which usually

- summarises the company background and the requested rate change

- accepts timely requests to intervene in the process

- notes the objections filed by the intervenors and discusses these objections

- finds that the proposed tariff changes raise issues that are best addressed in a public hearing

- issues an order accepting the tariff change for filing but suspending it for five months subject to refund and conditions and the outcome of the hearing

- orders an ALJ to be selected by the Chief ALJ, to convene a pre-hearing conference within 20 days in order to establish a procedural schedule, and to conduct further proceedings including the hearing, and

- may reserve certain other terms and condition issues, not set for hearing, for a technical conference and for report by Advisory Staff.

\section{The procedural schedule}

The Chief Judge appoints an ALJ within a week of the suspension order (median 4 days, range $1-6$ days). The pre-hearing conference is convened about two weeks later (median 13 days, range 6 to 21 days). ${ }^{18}$ The parties discuss and agree a procedural schedule for the case, consistent with processing time standards set by the Chief Judge. In practice, the pipeline usually proposes a first draft of the schedule, FERC and other parties comment, and an agreed schedule is put to the ALJ.

FERC has established three standards for cases: Simple (Track 1), Complex (Track 2) and Exceptionally Complex (Track 3). Gas pipeline section 4 rate cases are set on Track 3, which requires the hearing in 42 weeks (9 1/2 months) and the ALJ's initial decision in 63 weeks (about 14 months), from the ALJ's appointment. ${ }^{19}$ These targets are generally met. ${ }^{20}$ They have the merit that parties know where they stand with respect to process - at least, up to the point where the Commission itself has to take a decision. There are no guidelines or targets for Commission decisions, and indeed this is where the durations and uncertainty are greatest.

The schedule specifies about a dozen main dates in the proceeding, including dates for testimony, answering and rebuttal, joint statement of issues, commencement of hearing, briefs, and initial decision. There are also deadlines for discovery (information) requests and responses. In the HIOS case, the procedural schedule also made early provision for

(28 members), and three other groups (Indicated Producers, Southern Cities and Southern Company Services Inc) with 4 or 5 members each, making a total of nearly 80 interested parties.

18 There seems to be some inverse correlation between these two processes, so the net result is that the pre-hearing conference is convened about two weeks after the suspension order (median 14 days, range 12 - 25 days).

19 Section 5 cases are put on the faster Track 2 because refunds cannot be made until the case concludes. Electricity cases are usually put on the faster Track 1 or 2 because a hearing judge is appointed after the information discovery process and after an attempt at settlement has failed.

20 FERC's targets are that $75 \%$ of cases should be met within the stated times. In 2007 the achievement rates were $80 \%$ of Track 2 cases and $88 \%$ of Track 3 cases. There were no Track 1 cases that year. (FERC 2010 p. 88) 
the parties to advise the ALJ as to the status/likelihood of any settlement (about two weeks after the expected date of Trial Staff's first settlement offer).

The parties are always offered the facilities of a settlement judge at no charge. In practice they usually decline.

If a settlement is achieved, the hearing is suspended. Absent a settlement, the ALJ hears the case, and conveys an initial decision to FERC. The parties file 'exception briefs' on this, taking exception to particular findings of fact or conclusions of law. The ALJ's initial decision becomes the final decision unless FERC's final order specifies otherwise. The Commission may modify elements of the ALJ's initial decision - for example, to reflect a disagreement on some issue or evolving Commission policy. The Commission's order, which can be extensive and not necessarily unanimous, may be appealed. In some cases the final order and appeal process may take years.

\section{FERC's policy and role}

FERC's policy has long been in favour of settlements. ${ }^{21}$ FERC has acknowledged that it would be unable to cope with the flow of business in their absence. Moreover, settlements are useful "to determine the general positions of the parties and the issues which may ultimately be the subject of litigation”. (Walker p. 345)

OAL assembles a Trial Staff team for each case, comprising economists, finance experts and engineers. Typically there would be 2 attorneys, 2 supervisors (1 legal and 1 technical), and 4 to 10 analysts (on average 6). The team might be involved on the case for 5 months or more. Each member of the team might be working on two or more cases at the same time. If settlement is not reached, the same team stays on the case for the subsequent litigation.

For many years FERC staff have facilitated settlements in various ways, notably by checking data, providing information and focusing the issues. (Spritzer p. 43) At one time, settlement discussions would take place only after Trial Staff and other parties had filed testimony in response to a company's section 4 filing. However, to prepare formal testimony is time consuming and costly (and parties may get unduly wedded to what they have written). Since the mid-1970s Trial Staff have presented their views and settlement proposals to the parties before their testimony is filed. If settlement discussions are successful, there is no need to file testimony.

\section{First Settlement Offer}

In response to the pipeline's filed proposal, Trial Staff's first task is to put together "an objective settlement position" (often called a 'top sheet') which is regarded as the First Settlement Offer. To that end Trial Staff request extensive additional information from

\footnotetext{
21 'This practice increases the probability of a successful outcome where all parties' concerns are addressed. ... The settlement of these cases is enormously beneficial to the energy consumers as it dramatically limits the time, expense and resources that the Commission and outside parties would otherwise need to devote to these cases. Further, the resolution of a case through settlement is likely to be more acceptable to the parties than a litigated outcome, and therefore reduces the likelihood of an appeal.” (FERC 2010 p. 18)
} 
the pipeline, via the discovery process. Other parties, too, are engaged in a similar discovery process, asking their own questions of the pipeline. It is said that this process frequently identifies errors in the pipeline's calculations. Trial Staff assess the relevant parameters (e.g. operating expenses, investment, rate of return on equity and capital structure, volumes, terms and conditions, etc). They carry out a full cost of service review, including cost allocation, overall revenue requirement and rate design.

The Settlement Offer might be around 100 pages in length including a 10-12 page summary. (For a smaller pipeline the total length might be around 50 pages.) The Offer is circulated to all participants (i.e. the pipeline and accepted intervenors); it is not made public, nor indeed is its despatch recorded in the Docket.

The first Settlement Offer is a 'first cut' at the issue, usually close to what Trial Staff's position would be in the event of a hearing. That is, it represents a relatively tough assessment of the pipeline's filed proposal. It is generally assumed that a company's filing contains an element of 'fat' that could be subject to challenge or bargaining. But the top sheet will be tailored to the specific circumstances. ${ }^{22}$ The pipeline's section 4 filing and Trial Staff's first Settlement Offer then typically constitute the range within which negotiations proceed. However, it is necessary to take account of the views of all parties, some of whom might argue for an outcome outside of this range.

\section{First Settlement Conference}

The scheduled time for the submission of testimony by Trial Staff and other parties is about 7 months from the ALJ's appointment (median 203 days, range 183 - 239 days). OAL policy is to make the first Settlement Offer 3 months (90 days) after the suspension order (the latter is about a week before the ALJ's appointment). I am told that this target is achieved plus or minus a week or so. About two weeks are required to prepare testimony in the event that agreement is not reached. This means that the parties have about 3 - 4 months to try to reach agreement before they need to cease negotiations and devote themselves to preparing testimony.

Trial Staff call the first Settlement Conference to explain the Offer and enable participants to indicate their positions. The median time from issuing the first Settlement Offer to holding the first Settlement Conference is 6 weeks (range 2 to 10 weeks). The Conference, chaired by the lead attorney on the Trial Staff team, typically takes one day, and is held at FERC's office in Washington DC.

The Conference is attended by Trial Staff and all intervenors and their representatives, experts and attorneys. It is not open to the public. A small case might have about 20 participants in the room, of which about 7 or 8 might be active. A large case might have up to 100 participants, of which about 60 might be active. I am told that $90 \%$ or more

\footnotetext{
22 For example, if the company filed an outrageous rate of return proposal, then Trial Staff might feel it necessary to counter it in Top Sheets with a lower rate of return proposal than they would normally propose. This would allow for future movement by intervenors when the pipeline lowers its proposal and then expects a similar offer back. Such judgements are part of Trial Staff's negotiating strategy.
} 
of the movement on the pipeline is typically represented directly in a case. Trial Staff seek to represent the interest of all parties, including those not in the room. ${ }^{23}$

Participants may support or criticise the first Settlement Offer, or raise issues not addressed. They may be more concerned about the distribution or structure of proposed charges than the overall level. There may also be trade-offs between different aspects of the proposal, and indeed between the overall rate and the terms and conditions. ${ }^{24}$

At this Conference there is a full exchange of views. The aim is that by the end of the day the pipeline should be aware of all issues and views. All parties take notes, but there is no formal record.

\section{Second Settlement Conference}

The pipeline responds by means of a counter-offer, perhaps the next day, perhaps in a couple of weeks, but mostly within a week. A second Settlement Conference is then held (median 3 weeks after the first Conference, range 1 to 21 weeks), and usually set for two days. During this period Trial Staff and perhaps others will formulate, propose and discuss various counter-offers.

Trial Staff's aim now is to try to get agreement among the various parties. Some parties may have contacted Trial Staff even before the first Settlement Offer, to provide information or views. Trial Staff prefer to formulate their first Offer without too much interaction. After that they are open to interaction with all parties. They will start contacting the parties before the second Conference, by phone or email, discussing what to focus on, what to take into account.

At the beginning of the second Settlement Conference, Trial Staff will usually ask the pipeline to leave the meeting while they explain their thinking to the other parties. They will then seek to integrate the views of other parties into a single agreed second Counter Offer. This process takes between one and four hours, typically about two hours.

With the pipeline back in the room, Trial Staff will present this second Counter Offer to the pipeline, explain their thinking, and indicate to what extent this Offer is supported by the other parties. There is then a break while the pipeline considers the second Counter Offer and the views expressed. The pipeline will then usually come back with its own Counter-Offer. Depending on how close the parties are to agreement, it may be decided to continue discussions that day, or to set another conference.

\footnotetext{
23 'Not all customers intervene in the proceedings. That is part of the reason that OAL exists. We represent the public interest, and part of that interest is the parties who are silent in the proceedings. Ensuring the final rate is just and reasonable is not only for the customers who participate in the proceedings, but for all customers of the pipeline.' Personal communication 26 August 2010.

24 For example, some customers may want a low rate from A to B, others from C to D. Some customers may be concerned about the rate for storage, others interested only in transmission charges. A pipeline might argue the need to reduce the daily 'out-of-balance' allowance from 5\% to $4 \%$, and the customers might indicate a willingness to accept that if the overall rate were slightly lower, which might be achieved by shaving a point off the allowed rate of return.
} 
In contrast to the early proposals, these later offers may be just a couple of pages, focusing on the key points of difference where concessions are being made. Stay-out and come-back provisions (see below) may be mooted in the later proposals, but it is not worth raising them until agreement seems likely.

\section{Reaching agreement}

In many cases (6 out of 9 in the recent sample) agreement in principle was reached by the end of the second Settlement Conference. In one case, a third Settlement Conference was required, and in two cases a fourth. In the sample of 9 cases, the median time to reach agreement (i.e. from the assumed time of Staff's first Settlement Offer to the date of the last Settlement Conference) was about 11 weeks. In 8 cases the range was about 5 to 14 weeks, within which the median time of the 'core' negotiating period (from the first to last Settlement Conference) was about 4 weeks (range about 1 to 9 weeks). In the ninth case (HIOS, see below) negotiation was broken off while testimony took place, and the total time was 27 weeks.

It takes time to understand and mesh the different interests of the different parties including different customers, not just to reconcile the interests of customers versus pipeline. To this end, the pipeline will typically arrange separate meetings with those groups of customers that are particularly affected by its proposals. In some cases the pipeline might agree to specific requests from specific customers that do not involve OAL or any other party. ${ }^{25}$

Trial Staff are proactive in these settlement discussions. For example, they may suggest to a party that it develop a memo on a particular issue so that others can properly understand it, or so that Staff can indicate the extent of their support or indicate respects in which the Commission would be unlikely to support the argument. Or Staff might indicate some respect in which a proposal is inconsistent with FERC procedure but could perhaps be reformulated so as to be consistent. Throughout the process, Staff will be indicating their availability to meet and discuss and help to bring about agreement.

Once agreement in principle is reached, the pipeline or the parties jointly file a motion to suspend the procedural schedule. ${ }^{26}$ In a few cases, time may begin to run out before the scheduled time for filing testimony. If there are still reasonably good prospects for achieving a settlement, Trial Staff might ask for postponement of the hearing process by one or two months. (There were no cases of this kind in the sample.) In practice, in almost all such cases, settlements are achieved within the additional period. If there are not good prospects for achieving a settlement - or if a pipeline wishes to assess the

\footnotetext{
25 Such deals do not mean discrimination or covert practices: all rates have to be set out in the settlement agreement. Moreover, in the course of business, any customer-specific discounts from published rates have to be publicly notified on the pipeline's website. The customer-specific deals negotiated during settlement might relate to operational issues that do not affect other parties (e.g. access to a particular service or a modification to a contract), and might not even be subject to FERC jurisdiction.

26 They explain to the ALJ that it is preferable to avoid spending additional time on discovery, collecting evidence and preparing testimony, and incurring additional litigation costs, when this output may well not be needed. Instead, the parties could better focus their efforts on preparation and drafting of settlement and related documents. The ALJ normally accepts this request.
} 
strength of the evidence to be filed by FERC and other parties before committing to a settlement - the process reverts to the previously determined hearing schedule. ${ }^{27}$

\section{Filing the settlement document}

If agreement is reached in principle, the pipeline drafts a Settlement Document, of some 15 to 40 pages. This sets out the agreed rates, and other backup information to the extent needed to explain how the settlement came about (for example, on cost of service or volumes assumed). In addition, there would be detailed schedules (about 2 to 20 pages) containing rate sheets, and specification of terms and conditions. There might also be moratorium ('stay out') and 'come back' provisions (see below).

This draft Settlement Document is circulated to all parties. In the past, it was customary to arrange a Settlement Drafting Conference in Washington DC to discuss the details of the wording. This can still happen but has now fallen out of favour since it is easier for participants to email comments. A revised draft Document is circulated, for discussion and agreement at an all-party telephone conference. If there is a Settlement Drafting Conference, very occasionally it is held in the pipeline's region, so as to get more participation from local experts and operators, and so that they can hear first hand the thinking behind the settlement.

The ALJ invites the parties to draft the ALJ's letter of certification to the Commission. They do this according to a fairly standard template. The agreed settlement is then filed with the ALJ and published. In the sample, from agreement in principle at the last Settlement Conference to publication of the settlement document takes a median six weeks (range 3 to 13 weeks).

\section{Comments and FERC decision}

In principle, there are then two rounds of published comments, for parties to indicate their acceptance or rejection of the settlement, and to respond to other comments. 5 days might be allowed for the first round, 3 to 5 days for the second. In practice, most settlements are unanimous, in which case there are few comments, all supportive, and no replies are needed. The ALJ then certifies the settlement as unanimous (or contested or partial) and refers it to the Commission. In the present sample, the median time from filing a full uncontested settlement to certification is between a week and a month (range 4 to 33 days). Certification of a partial or contested settlement, or one with a reserved issue (see below), takes about five weeks (range 33 to 39 days).

In the absence of further complications, the total time to reach a unanimous settlement and obtain certification is usually under six months from the time of Trial Staff's first Settlement Offer. In the present sample, excluding the HIOS case with a reserved issue, the median is about 5 months (range from $3 \frac{1}{2}$ to 6 months). The median Commission time to approve it was about $2 \frac{1}{2}$ months (range 1 to $4 \frac{1 / 2}{2}$ months) from certification. In contrast, the HIOS case with a reserved issue took 9 months from first settlement offer to certification, and another year to get Commission approval.

\footnotetext{
27 This happened in the HIOS case. The parties resumed discussions after filing testimony, and reached agreement just before the hearing was due to start.
} 


\section{Black box proposals}

A main element in most rate cases is the total revenue associated with the proposed rates. Initially, the discussions of the parties centre upon the calculations used in the traditional cost of service approach, and the different values of the parameters proposed by the pipeline, Trial Staff and others. When the parties are close to agreement it may be possible for the parties simply to agree to 'split the difference' on these parameters.

In some cases, certain parameters may be contentious, particularly the cost of capital (or return on equity) and traffic volumes. The parties may not wish to be seen to be taking particular positions or conceding ground on such parameters. Moreover, if such parameters are specified in a settlement then subsequent observed performance may provide a basis for FERC to investigate the situation. In some cases, the parties handle this by not including the details of the calculations in the Settlement Document; they include only the agreed rates, and perhaps some general guidelines. ${ }^{28}$

In other cases, one or other party might at some stage propose a 'black box' settlement, whereby the 'bottom line' rates or revenue are specified but without linking them to particular assumptions. Other parties can then assess this proposal by making their own preferred assumptions about the parameter values and comparing the resulting rates or revenue with the proposed settlement. These parties may counter with black box proposals of their own.

To the outsider, and indeed to FERC personnel not part of that Trial Staff team, almost all settlements may appear to be black box insofar as the Settlement Document gives no details of the calculations. However, settlements where the parameters are agreed but not made public are not 'true' black boxes to those involved in the negotiations. Indeed, even 'true' black boxes are the result of a series of earlier proposals that start from Staff cost of service calculations and begin to narrow down the differences between the parties. (By the same token, lack of transparency is not a major issue in practice since any party with an interest in the case and a concern about information can become an intervenor and get access to all the information disclosed in the course of negotiations.)

It is said that 'true' black box approaches happen about one third of the time, and are initiated about equally by pipelines and customers. Of the sample 11 full or partial settlements, 1 gave a complete build-up of rates, 4 said they had used a black box approach (i.e. a 'true' black box), and 6 gave little or no detail of the calculations underlying the settlement. ${ }^{29}$ The latter approach nonetheless indicates a cost of service approach, albeit without giving details of the calculations, because a 'true' black box approach would have been declared in the settlement document.

\section{An example of the negotiation process}

To illustrate the negotiation process, the following recent example refers to a small interstate pipeline with no storage facilities and essentially only one service offering.

\footnotetext{
${ }^{28}$ For example, one of the 9 sample cases specified a pre-tax rate of return but not the capital structure or return on equity.

${ }^{29}$ In Portland Natural Gas, short term rates were nost of service approach was in principle applicable
} 
On 29 June the pipeline filed for a rate increase, citing a need to invest significantly for reliability purposes and to meet safety requirements. It also noted higher operating expenses and a lower throughput since its last rate filing. It showed a projected total cost of service of $\$ 5.4 \mathrm{~m}$ and a billing determinant (volume of gas transmitted) of $1.52 \mathrm{~m}$ Dth [Dekatherm], to yield a requested rate of \$3.55 per Dth per month. (The allowed rate is the total cost of service divided by the billing determinant.) There were few intervenors: a distribution company and some state public utility commissions.

On 30 July FERC issued its suspension order, suggesting that a number of issues might be explored at the hearing, including (1) the appropriateness of the proposed cost allocation and rate design (2) the level of the overall revenue requirement (3) the appropriateness of the proposed 11.50 percent return on equity and capital structure (4) the level of the depreciation rates and (5) the billing determinants.

A settlement conference was scheduled for 6 October, when Trial Staff issued their Top Sheet calculation with total cost of service $\$ 4.0 \mathrm{~m}$ and volume $2.01 \mathrm{~m}$ Dth leading to a rate of $\$ 1.98$. On the same day (exceptionally) intervenors independently made their own proposal assuming a total cost of service of $\$ 3.5 \mathrm{~m}$ and the same volume of $2.01 \mathrm{~m}$, implying a rate of $\$ 1.76$. Trial Staff and intervenors assumed broadly historic levels of investment and rate base, operation and maintenance expenses, depreciation expense and volume whereas the pipeline was projecting greater future investment, higher rate base and O\&M expenses, faster depreciation and lower future volume. The pipeline argued for $8.81 \%$ (overall) rate of return, Trial Staff for $8.19 \%$ and intervenors for 8.01\%. In broad terms, intervenors were arguing for one third higher volume, one third lower cost of service, and a consequent rate that was half the level that the pipeline proposed. The main difference on cost between the parties related to the regulatory rate base (reflecting the amount of new investment) and the allowed rate of return thereon.

The parties agreed to exchange information and to meet for a second settlement conference on 4 November, before which the pipeline would circulate a revised proposal. On 3 November the pipeline offered a significantly smaller increase in new investment, some reduction in the other cost items and a slightly modified return of $8.58 \%$, hence a total cost of service of $\$ 4.9 \mathrm{~m}$, some $10 \%$ less than before. It assumed a $5 \%$ higher volume at $1.60 \mathrm{~m}$. The combination implied a rate of $\$ 3.05$, some $14 \%$ lower than before.

At the settlement conference, intervenors revised their own offer, now basically accepting the pipeline's investment plan. They also moved towards the pipeline on other cost items, but (surprisingly) suggested an even lower rate of return at $7.99 \%$. Nonetheless the proposed total cost of service of $\$ 4.3 \mathrm{~m}$ was some $21 \%$ higher than their previous offer. Since the initial rate filing, the pipeline had signed a new contract with a user, and this evidence enabled the intervenors to accept a volume of $1.62 \mathrm{~m}$, essentially equal to the pipeline's revised assumption, which was a $20 \%$ reduction in volume from the intervenors' initial (historical) position. These assumptions implied a rate of $\$ 2.65$, an increase of about 50\% on the intervenors' first proposal.

At this point, the difference in rate between the pipeline and intervenors had reduced from $\$ 1.80$ to $\$ 0.41$ - that is, from about $65 \%$ (of a midpoint) to about $15 \%$. The parties then decided to focus on the bottom line rather than to debate particular cost items. During the day there followed three 'black box' offers and counter-offers, culminating 
in agreement in principle to a rate of $\$ 2.80$. The parties also agreed a billing determinant (volume) of $1.60 \mathrm{~m}$, as per the company's second proposal, and a cost of service of $\$ 4.47 \mathrm{~m} .{ }^{30}$ Compared to their second offers, this represented a concession of about $8 \%$ by the company and $6 \%$ by the intervenors: in other words, it roughly split the remaining difference between them. The parties agreed to circulate a draft settlement agreement on 10 November and the pipeline agreed to file an offer of settlement on or about 30 November.

\section{Non-unanimous or contested settlements}

As noted, settlements do not have to be unanimous. If contesting parties or contested issues are "severable", then the Commission may sever (carve out) and approve the uncontested portions. If there is unanimous agreement, a settlement is likely to say that it must be taken as a whole, and that any modification to it would render it null and void. But if it is not unanimous, or if there is likely to be sustained opposition to the settlement or parts of it, the language often allows the Commission to sever particular parties or issues. The consenting parties agree to be bound by the settlement, and to pay the rates in the settlement. The non-consenting parties then go to hearing, which will determine the outcome for them, and which may be better or worse than the outcome that the contesting parties have agreed under the settlement. Meanwhile the nonconsenting parties pay the higher rates in the section 4 proposal.

Are non-unanimous settlements likely to be frequent? A utility will normally try to ensure that Trial Staff and state regulatory commissions are on board with a settlement. Occasionally a large user might feel sufficiently aggrieved and willing to bear the burden of objecting to an otherwise unanimous settlement. However, the uncertainty about the outcome and the cost and burden of carrying a case alone make nonunanimous settlements unattractive to dissenting parties. (Trial Staff is likely to make this point in the course of negotiations. In those US State commissions whose rules do not permit severability, individual complainants have greater 'hold out' power.)

The evidence suggests that non-unanimous settlements are indeed abnormal. They do occur, as in the recent case of Florida Gas Transmission Company (Docket RP10-21). One customer, Infinite Energy, objected to "only one non-essential component of the Settlement”. Trial Staff and other parties argued that Infinite Energy's opposition to the Settlement was without merit, and that acting favourably on its comments might well destroy all of the substantial benefits of the settlement. The ALJ found that the objection did not raise any genuine issues of material fact, and certified the contested settlement. In the light of this initial decision, which meant that Infinite Energy would have had to carry the case on its own, Infinite Energy withdrew its opposition and the Commission approved the now-unanimous settlement.

Non-unanimous settlements can be problematic for Trial Staff. Neither the settlement itself nor arguments raised in the course of negotiations may be used in evidence in a subsequent hearing. If a non-unanimous settlement goes to a hearing, Trial Staff may

\footnotetext{
30 FERC requires a settlement to specify the rate and also depreciation rates. In this case the negotiation process had led to agreement on depreciation rates. The parties had also come to agreement on volume and total cost, and specified these in the settlement, which is not always the case.
} 
find themselves in a difficult position. Although they would prefer not to get involved, they wish to protect the interests of those who have accepted a settlement in line with their own recommendations, and indeed to protect the public interest. For example, suppose that the pipeline's original filing involved an implausibly high cost of capital, but the dissenting party's case involved an unrealistically low cost of capital. In the absence of further testimony, the Commission would be forced to choose one or other of these inappropriate values. Trial Staff might therefore feel obliged to provide testimony for a more reasonable value, in order to give the Commission that option.

\section{Partial settlement and reserved issues}

Partial settlements, where the parties agree on some issues and leave other issues for the Commission to decide at a hearing, are possible but again not common. This is not surprising: parties would need to feel that they are comfortable with the settled issues regardless of what the Commission might decide on the unsettled issues, even if its judgement is quite unexpected. It is not often that parties feel this.

Two cases from 2008 and 2009 are nonetheless recent examples of partial settlement. After a year's discussion and initial testimony, the parties in Portland Natural Gas were able to agree rates for certain short-term services but left the bulk of the issues for hearing. After many negotiations, the parties in El Paso Natural Gas (EPNG) were eventually able to agree all but four issues.

Sometimes the parties find that deferring a difficult issue, leaving room for the parties to pursue their own causes later, helps to provide a way through. In the same El Paso case, the parties could not agree whether to continue with a 'postage stamp' rate design for fuel reimbursement or to change to a mileage-based approach. The settlement had a moratorium on section 4 and 5 filings but explicitly provided that the users could file a complaint against the postage stamp design if they wished. ${ }^{31}$

As an alternative to a contested or partial settlement, parties may affirm that they have reached a settlement that should be sent to the Commission as uncontested, but they wish to reserve particular issues for the Commission to clarify or modify. They indicate, usually via a clause in the settlement, that they will accept the Commission's ruling on these reserved issues without the need for further evidence via a hearing. For example, in the HIOS case, the parties agreed that the settlement was uncontested but requested the Commission to decide on the applicability of a controversial storm damage repair surcharge.

In all three cases, the Commission's resolution of the non-settled issues is running into years rather than months. ${ }^{32}$

\section{Why settle?}

\footnotetext{
${ }^{31}$ One shipper has recently done so. Texas Gas Service Company, Docket RP10-951.

32 El Paso initial decision 514 days, final decision 420 days, total time $2 \frac{1}{1} 2$ years; Portland Natural Gas initial decision 802 days, final decision still outstanding; HIOS final decision on reserved issue still outstanding after a year.
} 
Why do parties settle rather than go to hearing? Some reasons are associated with process. Settlement is evidently quicker and less expensive than litigation and hearing. Admittedly it still takes time and cost to analyse a rate case and participate in the negotiating process. However, settlement saves on the cost of preparing and presenting testimony, cross-examination and subsequent briefs to the Commission. It means that company and customer management can get back sooner to the task of managing their businesses and Commission staff can move on to the next case.

Settlement reduces uncertainty about the outcome. The risks of litigation can be substantial. For example, when the parties are far apart on allowed Return on Equity (ROE), there is a real possibility that the ALJ would come down largely in favour of the other side, and/or that the Commission might adjust the ALJ's initial decision in an adverse way. To illustrate, in the recent SFPP oil pipeline case (Docket, the pipeline proposed 7.64\% ROE, with which the other parties and the ALJ were content. In contrast, in the recent Portland Natural Gas (PNG) case in the present sample, the pipeline proposed $14.75 \%$, the shippers $10.88 \%$, CAPP $10.81 \%$ and Trial Staff $11.39 \%$; the ALJ decided on $11.65 \%$. The initial decisions by the ALJs were both in December 2009, and in both cases the Commission gave its final decision on the same day, 17 February 2011. The Commission decided to leave SFPP's allowed ROE at $7.64 \%$ despite subsequent increases in market yields, whereas it decided to increase PNG's allowed ROE from $11.65 \%$ to $12.99 \%$. Settlement could have avoided or at least reduced this risk exposure (which in the event worked to the disadvantage of PNG's customers).

Settlement brings sooner rate relief to customers. The pipeline files for a rate increase which is implemented after six months subject to refund. The outcome - whether of a settlement or a litigated process - is typically a lower than requested rate increase and hence a refund, but a settlement brings the refund more quickly. Although this represents a corresponding downside to a pipeline, there is limited advantage in holding on to excess revenues that will soon have to be refunded (although rate filings to address a temporary liquidity problem are not unknown). Early reduction of risk is important to investors. In addition, pipeline management can better determine its investment and dividend policy once its allowed revenues are determined, and can refine its marketing policy once the prices of its services are determined.

The other set of reasons for agreeing settlements is that they enable the parties to secure preferred outcomes that they legally could not, or likely would not, achieve under a litigated hearing process. This raises the question whether settlements make a difference, and if so in what respects settlement outcomes are different from litigated outcomes? Given that either side can decline to settle and revert to a litigated outcome, it is not to be expected that settlements would lead to systematically higher or lower prices and returns on investment. However, there are other respects in which settlements make a difference, as described in the next two sections.

\section{Stay Out (moratorium) and Come Back provisions}

Settlements provide assurance for pipeline and for customers, not least about their ability to continue to operate on the agreed terms. Some settlements therefore incorporate a Stay Out or moratorium provision. Typically, this provides that the 
pipeline may not initiate a section 4 request for a change of rate, and/or customers may not initiate a section 5 request for a rate investigation, during the settlement period.

In the present sample, 6 of the 11 full or partial settlements provided for a moratorium on both section 4 and section 5 requests ( 4 for 3 years and 2 for 5 years). One provided for a moratorium only on section 4 requests (for 3 years). 4 made no such provisions. ${ }^{33}$

Since 1992, pipelines have not been required to file rate applications every 3 years. This suited the pipelines as long as costs were not rising but did not necessarily protect customers if costs were falling. Trial Staff take the view that it is appropriate to enable all parties to re-examine market conditions on a regular basis to ensure that the rate design remains appropriate. Consequently, Trial Staff always put in their first Settlement Offer a 'come back' provision or time limit, with an obligation on the pipeline to refile its rates, usually after 3 years.

The inclusion and duration of a come back period are subject to negotiation. One view is that pipelines initially objected to a comeback period, but have since 'learned to live with it'. Another view is that pipelines are willing to agree a comeback provision - but only at a price in terms of a few basis points on the allowed rate of return. Either side might want a longer period for the certainty or protection it provides. However, the pipeline would argue for a shorter period if it expected soon to incur significant expenses that would constitute a legitimate basis for a rate increase. Similarly, customers would argue for a shorter period if they expected costs to reduce. (In the US rates are set and reset on the basis of actually incurred expenses, rather than projected future expenses as in the UK.)

Of the 11 sample settlements, all but 2 had come-back provisions. 2 had a come back provision after 3 years, one specified a minimum of $1 \frac{1 / 2}{2}$ years and a maximum of $4 \frac{1 / 2}{2}$ years, one had 4 years, and 4 had 5 years. One had an obligation to file a cost and revenue study within 5 years. Thus, although 3 years seems to be a preferred duration for the agreement and moratorium on rates, a somewhat longer period of about 5 years is more usually allowed before the pipeline must refile.

\section{Differences in other settlement terms}

In addition to Stay Out and Come Back provisions, settlements enable other outcomes that could not or would not have occurred via litigation. As noted, an earlier El Paso settlement provided for a cap on the rates in certain contracts for the entire life of those contracts. El Paso's 2010 settlement established three Working Groups to explore the possibility for mutual agreement on additional tariff and rate issues. Gas Transmission Northwest's 2007 settlement (Docket RP06-407) provided for PG\&E to split its very large contract with the pipeline into three separate contracts of different durations, which in due course enabled PG\&E to transfer part of its business to the new Ruby pipeline, thereby facilitating competition.

\footnotetext{
33 In some jurisdictions, there have been disputes over the implementation of agreements, and requests to reopen them. This has not been the case at FERC. A settlement is a legal and binding document. It is very rare to see challenges to its enforcement or requests for it to be reopened.
} 
Settlements provide flexibility on amortisation. FERC's standard practice might amortise a particular type of asset over (say) a 10 year life. It would be open to a settlement to agree that the asset would be amortized over (say) 5 or 15 years, and to specify the profile of that amortisation. This would have implications for the time path of rates and revenues.

Settlements provide flexibility on refunds too. Suppose a pipeline had an authorised rate of $\$ 1.00$, filed to increase it to $\$ 1.20$ and a hearing later determined that the appropriate rate was only $\$ 0.80$. FERC could order a refund of revenues flowing from a rate in excess of the previously authorised rate of $\$ 1.00$. However, it would be open to a settlement to agree that the pipeline would refund revenues in excess of a rate of, say, $\$ 0.95$ (presumably in return for some concession by customers). In addition, a preferred date of refunding can be agreed.

Arrangements to spread risks and rewards associated with uncertain future demand have been developed in settlements, which could not form part of litigated decisions. Mojave's 2007 settlement included a mechanism for sharing with customers any revenues received above a specified level. Maritimes' 2010 settlement credits 50\% of annual interruptible revenues above \$9m pro rata to firm customers. Great Lakes’ 2010 settlement shares with qualifying shippers $50 \%$ of the revenue in excess of $\$ 500 \mathrm{~m}$ received over two years.

Settlements have included arrangements at variance with litigated decisions. Granite State, envisaging a series of future investments, recently proposed a capital cost surcharge that would track its capital costs and thereby obviate the need for several expensive and time-consuming section 4 rate cases over the next few years. It noted that the Commission had accepted capital cost trackers for other pipelines and said that it had modelled its own proposal on those. The Commission vetoed this, commenting that it had previously held that such costs should not be included in such surcharges, and that the tariff provisions mentioned by the pipeline "were approved as the result of settlements in those proceedings which do not establish Commission policy". ${ }^{34}$

Sometimes, parties may find a settlement attractive because it avoids the need to set precedents. The black box settlement has already been mentioned, where the parties do not commit to particular numerical calculations or indeed to particular lines of argument. Similarly, parties may construct a settlement to avoid the need for the Commission to set a precedent with respect to particular parameters or policies.

\section{Information and relations in the industry}

\footnotetext{
${ }^{34}$ Granite State requested a rehearing of this decision, pointing out the inconsistency of Commission policy. "The Commission has utterly failed to explain how a cost tracker or surcharge can be fair, reasonable, and in the public interest to warrant approval in a settlement agreement, but so unjust and unreasonable that it warrants outright rejection when presented directly in a rate case filing. On the one hand, the Commission states that such cost trackers are against the Commission's policies and regulations, while on the other hand, the Commission states that it will approve capital cost trackers if the parties agree to them during settlement proceedings.” Granite State Gas Transmission, Inc. Docket RP10896, Request for rehearing, 23 August 2010. Subsequently, Granite State agreed a settlement that did not include a capital cost tracker, and withdrew its requested rehearing.
} 
In Canada and some other US jurisdictions, regulators, companies and other parties have noted that negotiated settlements have generally led to better information flows and understanding in the industry, and to better relations between companies and customers. This may be an additional reason to settle. At FERC, too, it seems to be acknowledged that relationships are better with settlements than if litigation were the norm. Settlement processes provide a significant opportunity for customers to explain the nature of their business requirements and concerns to the pipelines and transmission companies, and at a time when these utilities are 'in listening mode'. Utilities, too, want their customers to understand their own positions. There are full and frank discussions, that are not possible in a formal hearing, and that may not be achieved during normal business activities because of the pressure of other issues. As noted, the issues discussed and on which agreement can be sought and reached are not limited to major headline issues of price. They can include all manner of detailed operational issues on which individual customers may have been seeking satisfaction for some time. This is not, of course, to claim that all relationships are good, as discussed below.

\section{Which cases settle?}

A thorough analysis of which cases settle and why would necessitate a much larger sample than the present 12 cases, including econometric analysis with time series and cross-section data over several jurisdictions. Nevertheless some insights can be obtained that might inform further research. Table 2 lists various potentially relevant characteristics.

Is settlement influenced by size of pipeline? Although some small pipelines are easier to deal with and some are harder, in general smaller pipelines have less complex issues and there is less revenue at stake. The 3 small (Non-Major) pipelines did indeed all settle in full without qualification. But some of the medium (Major), large (Top 30) and Mega (Top 16) pipelines did and others did not, so size is not the only factor.

Does pipeline size affect speed of settlement? The smaller pipelines have less complex issues. However, they may not have the staff and expertise to deal with FERC procedures, and may expect or necessitate more attention. Of the 8 cases that settled in full without a reserved issue, the average time to settle was 122 days for the 2 large and Mega pipelines, 143 days for the 3 medium ones and 137 days for the 3 small pipelines. This suggests that the professionalism and experience of the larger pipelines may be a more important factor in speed of settlement, even though their issues are typically more complex than those faced by other pipelines.

What about transactions costs? Table 2 indicates the number of protesting parties (i.e. filing formal arguments against the pipeline) and other intervenors (registering an interest in the case), and where available the number of signatories to the settlement. Number of parties is clearly not a main determinant of speed. A case with 43 parties and 227 signatories settled in the least time and the one case that failed to settle had only 6 parties.

Table 2 attempts to classify the cases in terms of complexity of the issues based on an informed qualitative assessment of the range of services at issue, the extent of differences between the parties, and the difficulty of the issues raised. Settlement might be easier with a relatively transparent and acceptable cost that has actually been 
Table 2: Characteristics of Section 4 Natural Gas Pipeline Rate Cases at FERC (2008 and 2009)

\begin{tabular}{|c|c|c|c|c|c|c|c|c|c|c|c|c|}
\hline Pipeline Company & $\begin{array}{l}\text { Previous rate } \\
\text { determination }\end{array}$ & $\begin{array}{l}\text { Pipeline } \\
\text { Location }\end{array}$ & $\begin{array}{l}\text { Pipeline } \\
\text { Capacity }\end{array}$ & $\begin{array}{l}\text { Proposed } \\
\text { Annual } \\
\text { Cost of } \\
\text { Service } \\
\end{array}$ & $\begin{array}{l}\begin{array}{l}\text { Number of } \\
\text { protestors, } \\
\text { intervenors, } \\
\text { signatories }\end{array} \\
\end{array}$ & Main Issues & $\begin{array}{l}\text { Susp. } \\
\text { Order } \\
\text { Pages }\end{array}$ & $\begin{array}{l}\text { Proposal } \\
\text { Complexity }\end{array}$ & $\begin{array}{l}\text { Pipeline } \\
\text { Customer } \\
\text { Satisfaction } \\
\text { Ranking } \\
\end{array}$ & $\begin{array}{l}\text { Moratorium? } \\
\text { years, s4, s5 } \\
\text { ComeBack? } \\
\text { years }\end{array}$ & $\begin{array}{l}\text { Calculation of } \\
\text { rates }\end{array}$ & $\begin{array}{l}\text { Outcome } \\
\text { Settlement } \\
\text { time } \\
\end{array}$ \\
\hline Saltville Gas Storage & First filing & $\mathrm{E}$ & $\begin{array}{l}\text { Non- } \\
\text { major }\end{array}$ & $\$ 29 m$ & 2,9, na & $\begin{array}{l}\text { Rate increase } \\
\text { (investment), } \\
\text { Fuel tracker }\end{array}$ & 1 & Simple & N/a & $\begin{array}{l}\text { M 3 s4 s5 } \\
\text { CB } 5\end{array}$ & No detail & $\begin{array}{l}\text { Settlement } \\
120 \text { days }\end{array}$ \\
\hline Portland Natural Gas & $\begin{array}{l}\text { Settlement } 2003 \\
+ \text { Comeback }\end{array}$ & $\mathrm{NE}$ & Major & $\$ 69 \mathrm{~m}$ & $5,15,5$ & $\begin{array}{l}\text { Rate increase } \\
\text { Short-term rates }\end{array}$ & 1 & Average & $\begin{array}{l}\text { Problematic } \\
\text { during process }\end{array}$ & M 5 s4 s5 & $\mathrm{N} / \mathrm{a}$ & $\begin{array}{l}\text { Partial } \\
\text { settlement } 330 \\
\text { days }\end{array}$ \\
\hline Southern Star Central & Settlement 2005 & MW & Top 30 & $\$ 257 \mathrm{~m}$ & 10,20 , na & $\begin{array}{l}\text { Rate increase } \\
\text { (investment) } \\
\text { New mechanisms } \\
\text { Changed T\&C }\end{array}$ & 3 & Average & 3 & CB 5 & Full detail & $\begin{array}{l}\text { Settlement } \\
132 \text { days }\end{array}$ \\
\hline El Paso Natural Gas & Settlement 2007 & SW & Mega & $\$ 650 \mathrm{~m}$ & $25,54,36$ & $\begin{array}{l}\text { Rate increase } \\
\text { New services } \\
\text { Changed T\&C } \\
\text { Article } 11.2\end{array}$ & $6+\mathrm{TC}$ & Complex & 32 & $\begin{array}{l}\text { M 3 s4 s5 } \\
\text { CB 3 }\end{array}$ & Blackbox & $\begin{array}{l}\text { Partial } \\
\text { settlement } 526 \\
\text { days }\end{array}$ \\
\hline Stingray Pipeline Co. & Settlement 2002 & Gulf & Major & $\$ 20 \mathrm{~m}$ & $1,3,4$ & $\begin{array}{l}\text { Rate increase } \\
\text { Event surcharge }\end{array}$ & 2 & Simple/Ave & $\mathrm{N} / \mathrm{a}$ & CB 3 & Blackbox & $\begin{array}{l}\text { Settlement } \\
174 \text { days }\end{array}$ \\
\hline Paiute Pipeline Co. & $\begin{array}{l}\text { Settlement } 2005 \\
+ \text { Comeback }\end{array}$ & $\mathrm{W}$ & $\begin{array}{l}\text { Non- } \\
\text { major }\end{array}$ & $\$ 35 \mathrm{~m}$ & 3,6, na & Rate increase & 1 & Simple & $\mathrm{N} / \mathrm{a}$ & CB $1 \frac{1 / 2-41 / 2}{1 / 2}$ & Little detail & $\begin{array}{l}\text { Settlement } \\
143 \text { days }\end{array}$ \\
\hline Vector Pipeline & $\begin{array}{l}\text { Settlement } 2004 \\
+ \text { Comeback }\end{array}$ & MW & Major & $\$ 115 \mathrm{~m}$ & 1,10 , na & Rate decrease & 1 & Simple/Ave & 29 & M 5 s4 & Blackbox & $\begin{array}{l}\text { Settlement } \\
113 \text { days }\end{array}$ \\
\hline Southern Natural Gas & $\begin{array}{l}\text { Settlement } 2005 \\
+ \text { Comeback }\end{array}$ & SE & Mega & $\$ 631 \mathrm{~m}$ & $18,43,227$ & 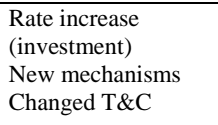 & $3+\mathrm{TC}$ & Average & 5 & $\begin{array}{l}\text { M 3 s4s5 } \\
\text { CB } 4\end{array}$ & No detail & $\begin{array}{l}\text { Settlement } \\
112 \text { days }\end{array}$ \\
\hline $\begin{array}{l}\text { High Island Offshore } \\
\text { System }\end{array}$ & Settlement 2007 & Gulf & Major & $\$ 58 \mathrm{~m}$ & $4,11,8$ & $\begin{array}{l}\text { Rate increase } \\
\text { Hurricane damage } \\
\text { Revised rate defns }\end{array}$ & 2 & Simple/Ave & $\begin{array}{l}\text { Problematic } \\
\text { during } \\
\text { process? }\end{array}$ & $\begin{array}{l}\text { M 3 s4 s5 } \\
\text { CB } 5\end{array}$ & Blackbox & $\begin{array}{l}\text { Settlement+ } \\
\text { Res. Issue } \\
268 \text { days }\end{array}$ \\
\hline MoGas Pipeline & $\begin{array}{l}\text { Merger Order } \\
2007 \\
\text { + Comeback }\end{array}$ & MW & $\begin{array}{l}\text { Non- } \\
\text { major }\end{array}$ & $\$ 17 \mathrm{~m}$ & 3,5, na & $\begin{array}{l}\text { Rate increase } \\
\text { (merger,investment) }\end{array}$ & 1 & Simple & $\mathrm{N} / \mathrm{a}$ & $\begin{array}{l}\text { M 3 s4 s5 } \\
\text { C\&R 5 }\end{array}$ & No detail & $\begin{array}{l}\text { Settlement } \\
148 \text { days }\end{array}$ \\
\hline Maritimes \& NE & $\begin{array}{l}\text { Settlement } 2006 \\
\text { + Expansion } \\
\text { Comeback }\end{array}$ & $\mathrm{NE}$ & Major & $\$ ?$ & $8,24,21$ & $\begin{array}{l}\text { Rate decrease } \\
\text { (expansion) } \\
\text { Fuel Retainage } \\
\text { Quantity/gas quality } \\
\end{array}$ & $1 \frac{1 / 2+\mathrm{TC}}{1}$ & Simple & $\mathrm{N} / \mathrm{a}$ & CB 5 & No detail & $\begin{array}{l}\text { Settlement } \\
141 \text { days }\end{array}$ \\
\hline Sea Robin Pipeline Co & Settlement 2009 & Gulf & Major & $\$ 18 \mathrm{~m}$ & $5,6,--$ & Hurricane surcharge & $1 \frac{1 / 2}{2}$ & Simple, Novel & $\mathrm{N} / \mathrm{a}$ & $\mathrm{N} / \mathrm{a}$ & $\mathrm{N} / \mathrm{a}$ & No Settlement \\
\hline
\end{tabular}


incurred, like a maintenance expense or a replacement pipe, than with a less transparent cost like the cost of capital, or a new investment where some parties might query the benefits to them of that investment. The Table also notes the number of pages devoted to summarising the issues in the suspension order. The 6 cases classed as Simple (with at most 24 other parties and 2 pages of summary) all settled in full, albeit in one case reserving an issue for the Commission. Of the 5 Average cases, 3 settled in full. The single Complex case (with 53 other parties and 6 pages of summary) part-settled. This suggests that simplicity facilitates settlement and that complexity hinders it.

On the other hand, it is also said that some issues lend themselves to litigation and decision by lay Commissioners whereas other more technical issues don't, so the parties prefer to settle the latter. This may simply mean that the parties make a more determined effort to settle such issues than they otherwise might. Or, more intriguingly, it might mean that, after a certain point, an increase in complexity means a greater rather than lesser likelihood of an issue being settled, because leaving such cases to the Commission is too awful to contemplate. Put more technically, is the probability of settlement monotonically decreasing or U-shaped as a function of complexity?

A comparison of the settled and non-settled issues in part-settled cases might throw light on this. The two part-settlements in the present sample do not suggest an easy answer. For example, the parties in Portland settled short-term rates but not long-term rates, whereas the parties in El Paso did the opposite. In Portland, the pipeline claimed they had settled "one of the most contentious areas of dispute in the case", whereas in El Paso the parties failed to resolve "perhaps the most difficult and complex aspect of the Stipulation". ${ }^{35}{ }^{36}$ Some therefore argue that settlement of complex issues depends on the specific circumstances of each pipeline and its customers, and each case is different.

Is settlement dependent on the pipeline's attitude? Reportedly, some pipelines have excellent relations with customers and look to build longer-term relationships; others do not and are said to prefer to gouge out the last dollar of profit. It is said that this reflects the management style of the pipeline, rather than other factors such as the extent of competition. Table 2 shows the ranking of the larger pipelines by their customers (in a table of 43 interstate pipelines). ${ }^{37}$ Two high-ranking pipelines settled quickly, but so did a lower-ranking pipeline.

One related suggestion is that practice reflects a cultural difference, with Midwestern pipelines tending to settle and pipelines serving the east and west coast tending not to. Table 2 shows that the 3 Midwestern pipelines did indeed settle in full. However, there are not sufficient observations from

\footnotetext{
35 This aspect related to Article 11.2 of the 1996 settlement, which had been left unresolved by the 2006 settlement, and in the present negotiations "the parties were unable to fully resolve the myriad issues relating to [it]", so they were now sending it for litigation to achieve some finality.

36 This aspect required interpretation of Article 11.2 of a previous 1996 settlement, which capped rates for certain existing contracts beyond the ten year term of that settlement. The question was whether that provision still applied (as the customers claimed) or whether circumstances had changed (as the pipeline claimed). The 2006 settlement did not resolve this question. In the present negotiations "the parties were unable to fully resolve the myriad issues relating to [it]", so "to achieve some finality" the parties agreed to litigate it. The ALJ's initial decision on 14 January 2011 held that the provision did still apply. The parties have challenged various aspects of this decision. The Commission has yet to issue its final order.

${ }^{37}$ Customer Satisfaction Index, Interstate Pipelines, Mastio \& Company, Natural Gas Transportation Customer Value Study, $15^{\text {th }}$ Edition 2011. (For discussion, see Erin Nelson, “Customer relationships keep pipelines focused in difficult market” Pipeline and Gas Journal, Vol 237 No. 12, December 2010, at http://www.pipelineandgasjournal.com/customer-relationships-keep-pipelines-focused-difficult-market) This Index defines a Mega pipeline as at least 3,500 miles, serving at least 3 states and delivering at least 1 trillion cubic feet. There are 16 Mega pipelines in its Index.
} 
other regions to provide a basis for distinguishing between the 5 other pipelines that settled in full and the 4 that did not.

Some suggest that pipeline attitude can be over-emphasised: all pipelines, however hard-hearted, have an interest in earlier and secure revenue flows. They suggest that personalities among the other parties must be considered too. Active leadership amongst these parties, enabling them to find common ground and see the utility's point of view, is also important. Although Trial Staff play this role, this view would say that Trial Staff cannot or do not play that role particularly well, although 'collegiality' - many participants being 'alumni' of FERC - does facilitate negotiation. This is an interesting idea, but it is difficult to identify personalities and leadership empirically.

Consider the characteristics of the 4 cases that did not settle in full and without qualification. El Paso that settled only in part is a large pipeline with complex issues of rate design and many different customers in different locations, hence with conflicting interests to reconcile, and not so highly thought of by its customers. Sea Robin that did not settle is a simple pipeline with no complex problems, the difficulty here being a proposed hurricane tracker provision for which precedent was disputed. HIOS which settled but reserved an issue for the Commission, and Portland Natural Gas which settled only in part, are both simple pipelines with a normal range of issues. They are not ranked in the Satisfaction Indexes but Portland's customers were noticeably aggrieved. ${ }^{38}$ Reportedly there were tensions with HIOS customers too.

The messages of this limited sample seem to be that a) small pipelines and simple issues typically settle, b) medium and large pipelines with averagely complex issues can also settle, c) novel issues and very complex issues involving conflicts between many customer groups are an obstacle to settlement, but also d) customer relationships and pipeline attitude to customer satisfaction seem relevant.

\section{Trend over time?}

The limited observations noted in the introduction to this paper suggest that settlements have become more frequent at FERC, from just over half the cases in the 1960s to around 90\% now. Why is this? Again, this properly requires a more extensive time-series and cross-section analysis. Factors commonly mentioned include the following.

- During the 1970s high inflation rates led to many more rate cases being filed, often requesting high rate increases that were difficult for customers to accept. In subsequent times of low inflation the fewer and more moderate requested rate increases were more amenable to settlement.

- $\quad$ FERC policy in favour of settlements reportedly strengthened in the late 1970s. (As noted, it was no longer deemed necessary for Trial Staff to file testimony before commencing settlement negotiations.) ${ }^{39}$ The industry, too, reportedly saw settlement as a 'win-win' approach.

\footnotetext{
38 For example, Portland Natural Gas Shippers Group were "surprised that Portland submitted the filing without providing for any advance public notice whatsoever, despite Portland's claims to the contrary". There are subsequent references to "disruption and prejudice", "pursuing discovery from PNGTS has been unusually burdensome and difficult”, "simply no basis for unfair and unsupported assertion by counsel for PNGTS” etc. Perhaps to make amends, Portland's motion to approve the settlement explicitly recognizes the "constructive approach" of its customers.

${ }^{39}$ However, FERC decisions in the late 1980s raised questions about contested settlements. (Walker 1986, Drom 1991)
} 
- $\quad$ FERC Order 636 of 1992, which removed the obligation to file rate cases every three years, seems to have reduced the number of rate cases to about one sixth of the previous level. It also simplified the cases, which now relate primarily to base rates reflecting the pipeline's own costs, not to the price of gas.

In the absence of a required filing every three years, come-back provisions may have been a significant factor in bringing rate cases in recent years. Of the 12 cases here, six reflect come-back provisions. ${ }^{40}$ A previous settlement seems likely to pre-dispose the parties to a further settlement but it is difficult to test this proposition since in all but two of the cases the rates previously obtaining were set by a previous settlement.

Settlements seem generally able to deal with cases where precedent has been established. When conditions are relatively stable, learning over time implies an increasing proportion of settlements. Changing conditions and innovation could disrupt this. In recent years the range of issues and instruments may have been increasing, but evidently not yet sufficiently to offset the trend towards more settlements. ${ }^{41}$

Is FERC unique, and if so why? FERC Staff seem more proactive than most US State commissions too proactive in the view of some parties. Nonetheless my impression - in the absence of explicit published accounts and data - is that settlements are more welcome at most US State commissions than they used to be. Some say budget pressures are a factor, since resources have not increased to cope with the more frequent and often annual filings associated with pass-through factors and 'riders'. Less inflationary conditions may have been a factor too. Settlement before State commissions may now be more common than litigated outcomes, but not close to the FERC figure of 80-90\%. A conjectured explanation for this difference is that rate increases at State level are more immediate and significant in terms of final customers, and hence more political, than at FERC, which deals only with interstate rates that typically form a smaller proportion of prices to final customers. In consequence, customer representatives before the State commissions - and indeed the State commissions themselves - need to be seen to be scrutinising and challenging rate increases, not simply agreeing them with the utilities.

\section{Pre-settlements}

If the parties normally find it possible and attractive to negotiate settlements of rate proposals filed by pipelines, would it not be possible to do this before rather than after the pipelines file the rate proposals? This would avoid the cost and uncertainty of filing and defending the case, and would also reduce the total time involved. It would not necessitate the involvement of FERC Trial Staff, and is in fact encouraged by FERC. ${ }^{42}$

\footnotetext{
${ }^{40}$ In one case this was contingent on a new investment rather than the previous settlement reaching maturity, in another case it was embodied in a Commission merger decision rather than in a settlement.

${ }^{41}$ Referees have suggested other factors possibly influencing settlement. DC legal counsel could have an interest in lengthy litigation rather than settlement, but presumably have a greater interest in a satisfied client. FERC advisory and trial staff and ALJs are not rewarded differentially for settling or litigating cases. FERC presumably has an interest in avoiding the resource problems that would occur if settlement were to decline significantly. There is no reason to believe that ALJs or Commissioners treat companies differently depending upon whether they have settled since failure to do so may have been attributable to other parties. There is no obvious reason why any of these factors would have changed over time.

42 “The Commission commends Dominion, PSCNY and the other parties in this proceeding for meeting with one another and negotiating their differences before making any filing with the Commission. This has enabled the quick processing of a rate reduction that benefits all of Dominion's customers, without the expense of a hearing and lengthy litigation. The
} 
Against this, it is said that other parties are reluctant: customers are suspicious of the pipelines, so that even if a rate reduction is proposed they are wary of giving something else away; the typically divergent interests in a rate case mean that each customer is fearful of not getting an appropriate outcome relative to other customers; and parties generally prefer to see what Trial Staff say in their first Settlement Offer before committing themselves.

Occasionally, however, pipelines do indeed file 'pre-settlements' before, or in lieu of, section 4 or section 5 proceedings. Wang lists two such cases in the six-year period 1994-2000. The main difficulty seemed to be getting all actual and potential customers on board. In 1995 the presettlement by Transwestern (RP95-271) was contested, but the Commission nonetheless approved it, noting that one of the few contesting parties was not in fact a current customer. In 1999 the Commission welcomed the settlement negotiated by Kern River with its firm customers, but withheld approval because "negotiations must include all those who have an interest in the outcome of those negotiations". ${ }^{43}$ Kern River later reached an accommodation that enabled the objector Sempra to consent to the settlement.

In 2005, Dominion negotiated a settlement rather than face a section 5 investigation (see below), and in 2006 Colorado agreed a settlement to obviate the need for a section 4 rate filing. For several years there were no further pre-filing settlements. However, despite the perceived difficulties, there were four pre-filing settlements in the middle of 2010, and two more in Spring 2011. (Table 3)

What factors are conducive to pre-settlement? Are they easier to achieve for smaller lines with fewer participants, offering fewer services with simpler issues? Pine Needle is indeed at the smaller end of the spectrum in terms of complexity, customer numbers and revenue. ${ }^{44}$ Trailblazer, Mojave, Venice and Carolina are all medium pipelines with a dozen or fewer signatories. But the four earlier presettlements (Transwestern, Kern River, Dominion and Colorado) are all by large (Top 30) pipelines. Thus, pipeline size, and any associated transactions costs, do not seem critical factors.

Staff are not involved in these pre-settlements so there is no summary of the company background and proposals issues as there is with section 4 and 5 rate cases. It is therefore not generally straightforward to assess the complexity of the issues involved. Pipeline ranking in terms of customer satisfaction is very varied. However, one feature is surely significant. All of the ten prefiled settlements followed a previous settlement (or even pre-settlement), six of which embodied a come back clause. Pre-settlement is thus more likely where the pipeline has previous experience of settlements.

\footnotetext{
Commission encourages other pipelines to act in a similar manner.” (Dominion Transmission Inc, Docket RP05-267, Commission approval, 27 May 2005)

${ }^{43}$ Kern River had not negotiated with Sempra, an interruptible and replacement shipper, which argued that it was adversely affected by the proposed settlement. After referring the matter to its Dispute Resolution Service, without success, the Commission approved the settlement as it applied to the consenting parties, and severed Sempra from the settlement, giving it an opportunity to litigate the sole issue of rate design as it applied to Sempra. On 30 January 2001 the ALJ held that Kern River's 'postage stamp rate design' was unjust and unreasonable for Sempra, and that Sempra's proposed zoned-based rate design was appropriate to be applied to Sempra. RP99-274-003, Initial Decision, January 30, 2001.

${ }_{44}$ Pineneedle is a liquefied natural gas (LNG) storage facility built in 1999, with a Customer Group comprising 4 parties plus North Carolina Utilities Commission, and annual revenue of $\$ 14.65 \mathrm{~m}$.
} 
Table 3 Pre-filing settlements

\begin{tabular}{|c|c|c|c|c|c|c|c|}
\hline $\begin{array}{l}\text { Pipeline } \\
\text { Company }\end{array}$ & Docket & $\begin{array}{l}\text { Filed } \\
\text { Approved } \\
\end{array}$ & $\begin{array}{l}\text { Location } \\
\text { Served }\end{array}$ & $\begin{array}{l}\text { Pipeline } \\
\text { Capacity }\end{array}$ & $\begin{array}{l}\text { Number } \\
\text { of } \\
\text { parties }\end{array}$ & $\begin{array}{l}\text { Customer } \\
\text { Satisfaction } \\
\text { Ranking } \\
\end{array}$ & $\begin{array}{l}\text { Previous rate } \\
\text { determination }\end{array}$ \\
\hline ranswestern & $\begin{array}{l}\text { RP95- } \\
271\end{array}$ & $\begin{array}{l}2 \text { May } \\
1995 \\
27 \text { July }\end{array}$ & $\mathrm{W}$ & Top 30 & $10-20$ & 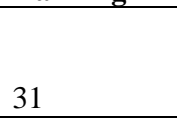 & Settlement 1994 \\
\hline Kern River & $\begin{array}{l}\text { RP99- } \\
274\end{array}$ & $\begin{array}{l}31 \text { March } \\
1999 \\
9 \text { Feb } \\
2000 \\
\end{array}$ & $\mathrm{~W}$ & Top 30 & 22 & 1 & $\begin{array}{l}\text { Settlement } 1995 \\
+ \text { Comeback }\end{array}$ \\
\hline $\begin{array}{l}\text { Dominion } \\
\text { Transmission }\end{array}$ & $\begin{array}{l}\text { RP05- } \\
267\end{array}$ & $\begin{array}{l}\text { 1 April } \\
2005 \\
27 \text { May } \\
\end{array}$ & $\mathrm{NE}$ & Mega & 26 & 12 & Settlement 2001 \\
\hline $\begin{array}{l}\text { Colorado } \\
\text { Interstate Gas }\end{array}$ & $\begin{array}{l}\text { RP06- } \\
397\end{array}$ & $\begin{array}{l}20 \text { June } \\
2006 \\
7 \text { August }\end{array}$ & Central & Top 30 & 7 & 17 & $\begin{array}{l}\text { Settlement } 2002 \\
\text { + Comeback }\end{array}$ \\
\hline Trailblazer & $\begin{array}{l}\text { RP10- } \\
492\end{array}$ & $\begin{array}{l}12 \mathrm{Mar} \\
2010 \\
30 \text { April }\end{array}$ & MW & Major & 8 & 37 & $\begin{array}{l}\text { Settlement } 2004 \\
+ \text { Comeback }\end{array}$ \\
\hline Mojave Pipeline & $\begin{array}{l}\text { RP10- } \\
1082\end{array}$ & $\begin{array}{l}16 \text { Aug } \\
2010 \\
28 \text { Oct } \\
\end{array}$ & $\mathrm{W}$ & Major & 7 & $\mathrm{~N} / \mathrm{a}$ & $\begin{array}{l}\text { Settlement } 2007 \\
\text { + Comeback }\end{array}$ \\
\hline $\begin{array}{l}\text { Venice } \\
\text { Gathering } \\
\text { System }\end{array}$ & $\begin{array}{l}\text { RP10- } \\
1280\end{array}$ & $\begin{array}{l}3 \text { Sept } \\
2010 \\
15 \text { Oct }\end{array}$ & Gulf & Major & 11 & $\mathrm{~N} / \mathrm{a}$ & Settlement 2001 \\
\hline Pine Needle & $\begin{array}{l}\text { RP10- } \\
1284\end{array}$ & $\begin{array}{l}9 \text { Sept } \\
2010 \\
\text { Mar } 30 \\
2011 \\
\end{array}$ & SE & Non-major & 5 & $\mathrm{~N} / \mathrm{a}$ & $\begin{array}{l}\text { Settlement } 2007 \\
\text { + Comeback }\end{array}$ \\
\hline Carolina Gas & $\begin{array}{l}\text { RP11- } \\
2076\end{array}$ & $\begin{array}{l}\text { April } 29 \\
2011 \\
\text { Awaited }\end{array}$ & $\mathrm{SE}$ & Major & 12 & 7 & Settlement 2006 \\
\hline $\begin{array}{l}\text { Colorado } \\
\text { Interstate Gas }\end{array}$ & $\begin{array}{l}\text { RP11- } \\
2107\end{array}$ & $\begin{array}{l}12 \text { May } \\
2011 \\
\text { Awaited }\end{array}$ & Central & Top 30 & 16 & 17 & $\begin{array}{l}\text { Pre-Settlement } \\
2006 \text { + Comeback }\end{array}$ \\
\hline
\end{tabular}

\section{Settlement of Section 5 cases}

Section 5 cases are where FERC or another party initiates an investigation with a view to securing reductions in potentially excessive rates, typically as indicated by the financial and operating information filed annually in Form 2. Regulatory bodies are generally reluctant to bear the burden of challenging existing rates. (Joskow 1974) Until recently FERC had reportedly not brought a section 5 case for several decades. Nevertheless, from time to time such cases happen. Would a pipeline would be willing to negotiate a rate decrease rather than go to hearing?

Consistent with experience in Florida (Littlechild 2009a), the evidence shows that it would. When the Public Service Commission of New York (PSCNY) notified Dominion in fall 2004 of its intention to file a section 5 complaint, Dominion and PSCNY negotiated a rate reduction in early 2005. ${ }^{45}$

\footnotetext{
${ }^{45}$ Docket RP05-267, FERC Order approving uncontested settlement, 27 May 2005, p. 2. Dominion lists no less than 78 customers (representing at least $85 \%$ of Dominion's annual revenue) as signatories to the pre-filed settlement. The settlement incorporated limited amendment to previous settlements, leaving in place the settled resolution of a series of complex issues on Dominion's system. It nonetheless involved a $\$ 49 \mathrm{~m}$ reduction in Dominion's annual revenues, totalling $\$ 245 \mathrm{~m}$ over the 5 years of the settlement.
} 
Dominion commented that the outcome showed that the Commission's existing methods of rate regulation worked effectively. PSCNY and two of the parties took issue with that claim. FERC subsequently responded to the debate, and to suggestions that some pipeline returns were unreasonably high and needed examining. In March 2008 its Order 710 required gas pipelines to report more detailed financial information. On the basis of that information, FERC concluded that three pipelines - Natural, Northern (both Mega) and Great Lakes - 'may be substantially overrecovering their cost of service, causing their existing rates to be unjust and unreasonable' ${ }^{46}$

In each case the pipeline had previously reached a settlement, but the settlement period had expired some years ago and there was no comeback provision. On 19 November 2009 FERC issued section 5 orders. As with section 4 cases, Trial Staff reviewed the information and put forward an initial settlement offer. Two of the pipelines proposed settlements that were accepted or not opposed by customers (74 settling parties in the case of Natural) and were supported by Trial Staff. ${ }^{47}$

Settlement discussions also took place with Northern. However, on 5 May 2010 the Northern Customer Group, consisting of seven of the largest shippers that held a majority of capacity on the pipeline, put forward a motion to terminate the section 5 proceeding, subject to Northern agreeing to an 18 month moratorium on proposing a section 4 rate increase. ${ }^{48}$ Several additional parties supported the Customer Group, including several state public utility commissions. Trial Staff and some other shippers were opposed. The Commission ordered the termination of the section 5 case, with the Chairman dissenting. Interestingly, Northern has one of the best customer satisfaction rankings among all pipelines, the other two being average. The outcome was in effect stimulated by a settlement, although not of a conventional kind.

A year later, FERC ordered investigations of two more pipelines. ${ }^{49}$ Again, they had previously reached settlement but without a comeback provision. Within six months, both had filed settlements, though not without some further controversy in one case. ${ }^{50}$

\section{Concluding remarks}

\footnotetext{
${ }^{46}$ Natural Gas Pipeline Company of America LLC, Docket RP10-147; Northern Natural Gas Company, Docket RP10148; Great Lakes Gas Transmission Limited Partnership, Docket RP10-149. These three pipelines are ranked $12^{\text {th }}$, $1^{\text {st }}$ and $19^{\text {th }}$, respectively, in order of size, and $1^{\text {st }}, 10^{\text {th }}$ and $5^{\text {th }}$, respectively, in NGSA's analysis of average profitability. They are ranked $24^{\text {th }}, 2^{\text {nd }}$ and $20^{\text {th }}$, respectively, in terms of customer satisfaction.

47 The rate reductions implemented were less than implied by FERC's initial calculations, and less substantial than first appeared. The bargaining power of the users was limited by the downturn in the economy, which had led to reduced volumes that might have justified an increase rather than reduction in rates if the matter had gone to hearing.

48 Docket RP10-148, Motion of Northern Customer Group to terminate section 5 proceeding and request for shortened comment period, 5 May 2010. The Commission had estimated an over-recovery of $\$ 167 \mathrm{~m}$ for 2008 , but Northern claimed that it under-recovered by about $\$ 63 \mathrm{~m}$ in 2009 . Northern projected increases in its cost of service and decreases in revenue from a sharp reduction in shipper demand, and informed its shippers that it intended to file a section 4 proceeding for a rate increase that would supercede the section 5 proceeding and also shift the risk of cost under recovery to the customers. Trial Staff submitted a settlement proposal that most parties supported but Northern rejected.

${ }^{49}$ Kinder Morgan Interstate Gas Transmission LLC Docket RP11-1494 and Ozark Gas Transmission, L.L.C. Docket RP11-1495, FERC press release 18 November 2010. Kinder Morgan is ranked $2^{\text {nd }}$ in NGSA's analysis of profitability and $40^{\text {th }}$ in the Customer Satisfaction Index. Ozark is not in either list.

${ }^{50}$ Kansas Corporation Commission was critical of the process ("FERC Trial Staff aggressively pursues hasty settlements") and of the pipeline's refusal to allow state commissions to participate in its proposed workshops on future tariff proposals. Docket RP11-1494, Initial Comments, May 10, 2011.
} 
FERC encourages negotiated settlements, and explains that it could not regulate without them. It observes that the use of settlements better addresses all parties' concerns, dramatically limits the time, expense and resources devoted to these cases, and provides an outcome more acceptable to the parties.

The proof of the pudding is in the eating. The parties involved have increasingly preferred settlement to litigation over the course of the last half-century. This is a remarkable record of survival in an activity - utility regulation - that has been characterised by no little reform and change over this period. Indeed, settlement is now actively chosen by all parties - utility, customers, interstate and state regulators - in some $90 \%$ of all section 4 rate cases. Recently, pipelines are choosing settlement as a means of reducing rates, in preference to resisting section 5 cases. Traditional litigation has become essentially a method of dispute resolution limited to novel or exceptionally difficult rate case issues.

A factor in this evolution has been the pro-active role taken by FERC Trial Staff and settlement judges. Trial Staff indicate their thinking on the key parameters as a basis for informed discussion by the parties. Thereafter, the regulatory aim is to bring the parties into agreement, not to impose a preconceived settlement upon them. Having given a lead, FERC seeks to facilitate the market process, not to replace it.

Nevertheless other factors are undoubtedly relevant. Further and more systematic research is needed to better understand what they are, and to compare outcomes over time and in different jurisdictions. A potentially significant development in the last couple of years is the pre-filing settlement, achieved without the aid of Trial Staff. Does this suggest that FERC's active process is not in fact instrumental in facilitating settlements? Or is pre-settlement a mark of the change in attitude that FERC's active process has helped to bring about?

\section{References}

Buchmann, A P and Tongren, R S. 1996. "Nonunanimous settlement of public utility rate cases: a response”. Yale Journal of Regulation 13, 337-345.

Chermak, Janie M. 1998. “Order 636 and the U.S. natural gas industry”. Resources Policy, 24 (4) December, 207-216.

Dahl, Carol A and Matson, Thomas K. 1998. "Evolution of the U.S. Natural Gas Industry in Response to Changes in Transaction Costs”, Land Economics, 74 (3) Aug, 390-408.

De Vany, Arthur and Walls, W David. 1994. "Natural gas industry transformation, competitive institutions and the role of regulation: Lessons from open access in US natural gas markets”, Energy Policy, 22 (9), September, 755-763.

Doane, Michael J and Spulber, Daniel F. 1994. "Open Access and the Evolution of the U. S. Spot Market for Natural Gas”, Journal of Law and Economics, 37 (2) Oct, 477-517.

Doucet, J and Littlechild, S C. 2006. "Negotiated settlements: The development of legal and economic thinking”, Utilities Policy, 14, 266-277. 
Doucet, J and Littlechild, S C. 2009. "Negotiated settlements and the National Energy Board in Canada”, Energy Policy, 37, October, 4633-4644.

Drom, R A. 1991. "Settlement of contested transportation rate cases at FERC: should the squeaky wheel be greased?” Energy Law Journal 12, 339-361.

Federal Energy Regulatory Commission (FERC). 2010. Congressional Performance Budget Request, Fiscal Year 2011, January.

Gorak, Thomas C and Ray, Dennis J. 1995. "Efficiency and Equity in the Transition to a New Natural Gas Market”, Land Economics, 71 (3), Aug, 368-385.

Herbert, John H and Kreil, Erik. 1996. “US natural gas markets : How efficient are they?” Energy Policy, 24 (1), January, 1-5.

Joskow, P L. 1974. "Inflation and environmental concern: structural change in the process of public utility price regulation”, Journal of Law and Economics 17, 291-327.

Krieger, S H. 1995. "Problems for captive ratepayers in nonunanimous settlement of public utility rate cases”. Yale Journal on Regulation 12, 257-343.

Littlechild, S C. 2009a. "Stipulations, the consumer advocate and utility regulation in Florida”, Journal of Regulatory Economics 35(1), February, 96-109.

Littlechild, S C. 2009b. “The bird in hand: stipulated settlements in the Florida electricity sector”, Utilities Policy, 17 (3-4), Sept-Dec, 276-287.

Rosenzweig, M and Shuttleworth, G. 2008. "RPI-X@20: Comments on the Bibliography of Alistair Buchanan's Speech (06/03/08)”, A Report for EDF Energy, NERA, London, 30 April.

Shuttleworth, G. 2008. “RPI-X@20: a plan for regulatory regime change”, Power UK, 178, December, 38-9. (Available on RPI-X@20 review pages at www.ofgem.gov.uk)

Spritzer, R S. 1971. "Uses of the summary power to suspend rates: an examination of federal regulatory agency practices”. University of Pennsylvania Law Review 120, 39-107.

Walker, M A. 1986. “Settlement practice at FERC: boom or bane”. Energy Law Journal 7, 343-359.

Wang, Z. 2004. "Settling utility rate cases: an alternative ratemaking procedure”, Journal of Regulatory Economics, 26 (2), September, 141-163. 